\title{
ULICHNYE FAMILII AMONG THE DOUKHOBORS OF THE CAUCASUS AND CANADA
}

Keywords: Doukhobor, Russia, Caucasus, Canada, ulichnye familii, surnames, folk custom

Along with their official surnames, many 19th century Doukhobors in the Russian Empire had another, unofficial surname by which they were also known. Referred to as ulichnye familii ('street surnames'), these names were used colloquially 'on the street' of a village to distinguish between families sharing a common surname and to assert new family identities. Similar to Quebecois dit names and Scottish sept names, ulichnye familii arose because of the low surname stock within Doukhobor society. When a large contingent of Doukhobors immigrated to the Canadian prairies in 1899 , they continued this naming practice in their settlements well into the early 20th century.

The occurrence of such names among the Doukhobors was first noted by E.A. Popoff in his 1956 work, 'Rasskazy iz Istorii Dukhobortsev'; however, to date, no comprehensive study has been undertaken to examine this folk custom.

This article offers an analysis of the Doukhobor anthroponymic custom of ulichnye familii: the social factors leading to their adoption; the etymological processes through which these names were formed; the manner in which they were used and transmitted; and the elements contributing to their eventual decline and disuse. It also includes an inventory of extant ulichnye familii among the Doukhobors of the Caucasus and Canada, obtained through extensive field interviews and archival research.

\section{SOCIAL ORIGINS AND CONTEXT}

The Doukhobors were a religious sect founded in 18th century Russia. They rejected the rites and dogma of the Orthodox Church and denied the authority of the Tsarist State, refusing to swear allegiance to anyone but God. Their pacifist, egalitarian and anti-authoritarian teachings were based on the belief that 
the spirit of God resides in the soul of every person. Perceived as a threat to the established order, the Doukhobors were frequently persecuted for their faith and exiled to the frontier regions of the Empire.

There, on the Russian borderlands, they established compact agricultural settlements, first in the Molochnaya region near the Sea of Azov after $1801^{1}$, followed by the Caucasus mountain region after $1841,{ }^{2}$ that retained a high degree of ethnic, cultural and religious homogeneity amongst themselves. Largely isolated from their environment by language, culture and religion, with even a measure of local political autonomy, the Doukhobors created a distinct and cohesive social, cultural and economic community; a veritable 'state within a state' or Dukhobor' $y e$ ('land of the Doukhobors'), comprised of like-minded persons committed to the same beliefs and way of life. The relative isolation and social conservativism of their society during the 19th and early 20th centuries helped to preserve aspects of traditional Russian folk culture, which in due course, assumed their own, uniquely Doukhobor traits. ${ }^{3}$

The folk custom of ulichnye familii was introduced into the Doukhobor milieu in the early 1800s by adherents of different regions of the Empire, where it was already widely practiced. ${ }^{4}$ Indeed, a number of the first Doukhobor settlers to arrive on the Molochnaya bore a second, informal name alongside their official surname. For example, in 1802, Dmitry Sysoev, also called Sukhachov, received permission to relocate there from Pavlograd uezd ('district'), Ekateri-

1 From 1801 to 1845 , Doukhobors across Russia were permitted to settle along the Molochnaya River in Melitopol uezd, Tavria guberniya in present-day Zaporozh'e oblast, Ukraine: See Staples, J. (2003). Cross-Cultural Encounters on the Ukrainian Steppe, Settling the Molochna Basin, 1783-1861. Toronto: University of Toronto Press.

2 From 1841 to 1845 , Molochnaya Doukhobors were exiled to the Akhalkalaki and Borchali uezds of Tiflis guberniya in present-day Ninotsminda and Dmanisi rayons, Georgia and Elisavetpol uezd and guberniya in present-day Gadabay rayon, Azerbaijan: See Breyfogle, J. (1998). Heretics and Colonizers: Religious Dissent and Russian Colonization of Transcaucasia. 1830-1890. University of Pennsylvania.

3 Inikova, S.A. (1999). Doukhobor Incantations through the Centuries. K.J. Tarasoff (Trans. Ed.). Ottawa: Legas \& Spirit Wrestlers Associates.

4 For Russian scholarship on the practice of this folk custom in various regions of Russia, see: Sumstov, N.F. (1889). Ulichnye Klichki. Kievskaya Starina (Tom 24), s. 404-417; Sumstov, N.F. (1890). Kul'turnye perezhivaniya. Kievskaya Starina (Tom 7), s. 41; Chichagov, V.K. (1959). Iz istorii Russkikh imen, otchestv i familii. Moscow: Uchpedgiz; Khudash, M.L. (1890). Do pitannya klasifikatsii Ukrains'kikh prizvishchevikh nazv XIV-XVIII st. Z Istorii Ukrains'koy Leksikologii, s. 123; Simina, G.Y. (1969). Familiya i prozvishche. Onomastika, s. 27-34; Tagunova, V.I. (1970). Famili vo Vladimirskoy i Gor'kovskoy oblastyakh. Antroponimika, s. 114-119; Gorelova, L.D. (2011). Ulichnye familii obrazovannye ot dialektnykh slov. Vestnik No. 13 (228), s. 44-48; Gorelova, L.D. (2012). Ulichnye familii. Russkaya Rech' No. 4, s. 128; Nedostupova, L.V. (2014). Ulichnye familii v Voronezhskoy oblasti. Russkaya Rech' (No. 3), s. 107-110; Tyurina, G.N. (2014). Ulichnye familii kak fragment onimicheskogo prostranstva sela Gremyachevo Kulebakskogo rayona Nizhegorodskoy oblasti. Gramota (No. 12), s 188-190. 
noslav guberniya ('province'). Similarly, in 1803, Ivan Sukrutov, also known as Trubitsin, resettled on the Molochnaya from Izium uezd, Sloboda-Ukraine guberniya. And in 1805, Dmitry Raspopov, also called Loskutov, relocated there from Morshansk uezd, Tambov guberniya. In these cases, Doukhobor settlers brought ulichnye familii to the Molochnaya that originated in their previous settlements in the late 18 th century.

In other cases, Doukhobor settlers adopted ulichnye familii soon after their arrival on the Molochnaya. This was particularly common among fugitives army deserters and escaped serfs - who clandestinely joined their coreligionists in Tavria guberniya. Once there, they assumed double names: one real and the other false, which they passed for under forged documents ${ }^{5}$. For example, in 1810, the army deserter Gavrila Tikhonov hid in Terpeniye village, Melitopol uezd under the name Dobrynin. In the same year, Nikita Kuchin, another army deserter, was concealed in Troitskoye village under the name Krylov. And, in 1815, the escaped serf Minai Ipakin was registered in Efremovka village as Dukhoborov. In these cases, Doukhobors used ulichnye familii as aliases to conceal their true identity from state authorities, while their real names were known to their coreligionists.

Yet despite these early antecedents, the adoption of ulichnye familii does not appear to have become widespread among Doukhobors until several decades later, when they resettled in the Caucasus. A detailed analysis reveals that while these names were continuously adopted throughout the late 18th to mid-20th centuries, most (129 of an identified sample of 275 names) originated during the 1841-1886 period, as evidenced by their derivation from names of heads of household during that era. It must be considered, therefore, how the folk custom achieved such prominence during this particular period of Doukhobor history.

\subsection{Social Differentiation}

By the mid to late 19th century, a population boom among Doukhobors in the Caucasus $(5,277$ persons in $1853 ; 8,925$ in $1873 ; 12,447$ in $1886 ; 17,825$ in 1897 ) led to the expansion of kinship groups and a proliferation of people sharing the same, relatively small stock of surnames (305 in total) within their settlements. In these circumstances, one increasingly encountered common namesakes in villages who may or may not have held familial ties.

For instance, in Akhalkalaki uezd in the 1870s, one finds eight Doukhobors named 'Ivan Kalmykov' in the village of Goreloye, seven named 'Ivan Kazak-

5 Inikova, S.A. (2003). Tsena ‘Tsarstva Bozh'ego' na Molochnykh Vodakh (1802-1841). Religiovedenie (No. 3). Blagoveshchensk: Izd. AmGU. 
ov' in Orlovka, six named 'Vasily Malov' in Spasskoye, six named 'Aleksei Chernenkov' in Bogdanovka, and so on. Thus, Doukhobors increasingly adopted ulichnye familii as a means of distinguishing among village households with the same surname by assigning new, informal names to them.

These alternate names came to be regularly used to differentiate branches of the same clan within a settlement. For example, in the village of Novo-Goreloye in Elisavetpol uezd, there were twelve related households bearing the surname Kalmykov in the 1870s; however, each household was commonly known by its own distinct 'street' surname: Gerasimov, Fedoseev, Finashin, Ignatov, Mitrov, Yashin, Vanin, and so on. Similarly, in the Tambovka village in Akhalkalaki uezd in the 1850s, there were three related households officially known as Ryl'kov, but informally known as either Trushin or Lazunin.

In the same manner, ulichnye familii were also used to distinguish between wholly unrelated Doukhobor families living in a village who happened to share a common surname. Hence, in Slavyanka village in Elisavetpol uezd, there were six households in the 1860s registered as Chernov who descended from two entirely separate family lines, and who were customarily known as either Mikolenkov or Mikheev. Likewise, in the village of Goreloye in Akhalkalaki uezd in the $1880 \mathrm{~s}$ and $1890 \mathrm{~s}$, there were five unrelated households legally recorded as Goncharov but unofficially known as Shkadronov, Gryakov, Chuparov, Skird$k o v$, and so on.

The preponderance of ulichnye familii among the Doukhobors was thus largely dictated by changing social and demographic conditions within their settlements in the Caucasus. These names became a necessary form of social differentiation in everyday conversation in order to designate specific families where common surnames failed to adequately do so. As such, they helped define and reinforce extensive kinship networks within Doukhobor villages.

\subsection{Social Re-Identification}

At the same time, if social differentiation was the primary function of ulichnye familii among the Doukhobors, it was not their sole purpose. As it turns out, there were some 19th century Doukhobor families using alternate names who were, in fact, the only household in their village bearing their particular surname.

For instance, in the village of Orlovka in Akhalkalaki uezd in the 1860s, the sole household bearing the surname Krygin was also informally known as $I v$ liev. And in Troitskoye village in Melitopol uezd in the 1840s, the only family registered as Kozlachkov was sometimes called Savinov. Also, in the village of Slavyanka in Elisavetpol uezd in the 1850s, the one household officially known as Petrov was commonly referred to as Anisin. 
In these circumstances, there was obviously no need to differentiate between other families in the vicinity bearing the same surname, because there were none. One must therefore consider other explanations for the use of ulichnye familii in these cases.

In all probability, some of these 19th century Doukhobor families, having lost any meaningful connection with their 17 th century ancestors (from whom their official surnames derived) adopted new, alternate names which they more readily identified with, and which held greater relevance and immediacy to them. This would explain the adoption of ulichnye familii when there was otherwise no need to distinguish themselves from other village families. Therefore, alternate names could also be used as an expedient means of social re-identification for families seeking to manifest a new, more suitable identity.

\section{TYPOLOGY OF FORMATION}

The etymological formation of ulichnye familii among 19th century Doukhobors was a dynamic, fluid and largely unpredictable process that was not subject to any formal rules or regulations. However, it can generally be said that they were identical in form to official surnames in Russia, and their formation involved either the creation of new names based on some attribute of the household head, or else variations in the form (or application) of their existing surname. With this in mind, it is possible to formulate a typology of mechanisms by which these names arose.

\subsection{Parallel Origins to Surnames}

By far and away, most ulichnye familii (254 of an identified sample of 275 names) among 19th century Doukhobors originated in the same manner in which official surnames formed in Russia, two centuries earlier. That is to say, they were derived from either the personal name, nickname, occupation or place of residence of a head of household, the figure of central authority in the large, extended multi-generational families prevalent among the Doukhobors of that period.

Imeni ('personal names') formed the basis of most (137 of an identified sample of 275 names) Doukhobor ulichnye familii. The majority (116 names), unsurprisingly, were patronymic since the head of household in 19th century Russia was customarily the eldest, dominant male of the family. Sometimes, the proper form of the man's name was used as the basis. For example: Nikitin from Nikita (D’yakov); Efremov from Efrem (Kireev); Kondratov from Kondrat (Konygin); and so on. More often, the diminutive form of the man's name was used, since Doukhobors customarily addressed one another in these terms. For instance: 
Aleksashin from Aleksasha, a diminutive of Aleksandr (Fofanov); Fedin from Fedya, a diminutive of Fyodor (Kazakov); Kostikov from Kostik, a diminutive of Konstantin (Salykin), etc.

Somewhat less common were ulichnye familii derived from women's names (21 names), since Doukhobor women of the period did not normally become heads of household unless their husbands were dead, incapacitated or absent and there was no suitable male replacement. Interestingly, those matronymic names that did arise almost always derived from the diminutive of the woman's name. Thus we encounter Arinin from Arina, a diminutive of Irina (Kalmykov); Manyukhin from Manyukha, a diminutive of Mariya (Agafonov); Ulyashin from Ulyasha, a diminutive of Uliana (Chernenkov); and so on.

Many ulichnye familii (92 of an identified sample of 275 names) were formed from klichki ('personal nicknames') given to 19th century Doukhobor heads of households. Nicknames were common among the Russian peasantry, and the sources from which they were drawn were almost endless, arising out of the everyday circumstances of rural village life. They might relate to size or stature: Malushkin from malushka or 'small' (Agafonov); physical appearance or traits: Bezborodin from bezboroda meaning 'beardless' (Gubanov); disability or ailment: Nemakhov from nemakh or 'mute' (Malakhov); behavior or personality: Michurin from michura meaning 'taciturn' (Nichvolodov); moral character: Dobrov from dobryi or 'good' (Bludov); names of animals: Kukanov from kukan meaning 'frog' (Oslopov); names of birds: Utkin from utka or 'duck' (Fofonov); articles of clothing: Chulkov from chulok or 'stocking' (Kazakov); and types of food: Kashkov from kashka, a diminutive of kasha or 'porridge' (Obed'kov); etc.

Even when the literal meaning of the nickname is clear, the reasons why it was given to a household head (and subsequently adapted as an ulichnaya familiya) often remain obscure. In some cases, oral tradition can provide the context behind a nickname. For instance, while the root of Sivkin (Agafonov) is clearly sivka, meaning 'greyish', it is only through oral tradition that we know the Agafonov family patriarch was so nicknamed because he owned a flour mill and was always covered in greyish flour dust. In many cases, however, the oral tradition explaining a nickname is no longer preserved, and the reasons can only be speculated upon.

Several ulichnye familii (17 of an identified sample of 275 names) were derived from trades and occupations of 19th century Doukhobor heads of households. Often, these related to agriculture and animal husbandry, which the sectarians engaged in almost exclusively: Konovalov from konoval or 'horse-doctor' (family unknown); Sitnikov from sitnik or 'flour sieve-maker' (Zbitnev); etc. Others reflected various callings prevalent at the time: Kovalev from koval meaning 'blacksmith' (Tarasov); Starshinov from starshina meaning 'village 
foreman' (Trofimenkov). Still others related to military service: Soldatenkov from soldatenka, a diminutive of soldatka or 'soldier's wife' (Strelyaev).

Relatively few ( 8 of an identified sample of 275 names) Doukhobor ulichnye familii were locational in nature. ${ }^{6}$ These might indicate a place of origin of a family: Lizavetsky, denoting a family who resettled from 'Elisavetpol' guberniya (Kalmykov). They could also describe the geographic features of a family's place of residence: Prudnisky, from prudnii meaning 'pond', 'dam' or 'embankment' (Chutskov). Others were more generic and denoted association or ownership: Koroninsky, of or belonging to the korona or 'crown' (Filippov).

Numerous ulichnye familii were formed from dialect words used by 19th century Doukhobors that differ from those spoken by modern Russians today. For instance: Lipatov (Kalmykov) is derived from the dialect verb lipet' ('to adhere') rather than the standard Russian lipnut'; and Kartopov (Agafonov) is derived from the dialect term kartop ('potato') rather than the standard Russian kartofel' or kartoshka. Still other ulichnye familii originated from loanwords borrowed from native Caucasian languages used where the Doukhobors settled; although these tend to be more numerous among 20th century names due to the greater degree of cultural assimilation. For example: Karabaev (Borisenkov), derived from the Azeri Turkic term karabai, meaning 'rich' and 'prosperous'; or Tatosov (Makaseev), derived from the Armenian men's name Tatos meaning 'fatherly'. These names illustrate the diverse local and linguistic factors influencing the formation of ulichnye familii among the Doukhobors during this period.

\subsection{Structural Changes to Existing Surnames}

Some ulichnye familii (17 of an identified sample of 275 names) among 19th century Doukhobors originated through structural changes to the existing surname of a household head rather than through the formation of an entirely new name. This involved partial changes in the morphological structure of the surname: either to the root, the suffix, or both.

The change could involve swapping the root element of the surname for a similar-sounding variant or derivative of the root. For example, in Slavyanka village in Elisavetpol uezd in the 1870s, the household of Ivan Parfenkov (from the men's name Parfen) was also called Panferkov (from Panferka, a diminutive of Parfen). Likewise, the household of Stepan Gerasimov (from the men's

6 Doukhobors often used locational bynames to identify families. For example, a Konkin family from Spasovka, Kars okrug might be identified as Konkin-Spasovsky to distinguish it from a Konkin family of another village. However, these bynames were typically neither fixed nor hereditary and could apply to any Doukhobor family living in that place. Hence, such bynames are not considered ulichnye familii for purposes of this work. 
name Gerasim) in Slavyanka in the 1860s was alternately known as Gerov (from Gerya, a diminutive of Gerasim).

The morphological change could also involve exchanging the suffix element of the surname for a different one. Often, this entailed the diminutization of the surname through the addition of the suffix -enko, which among Doukhobors connoted a 'lesser', 'poor' or 'unfortunate' branch of a family. Hence, in the village of Slavyanka in Elisavetpol uezd in the 1860s, the household of Prokofy Semenishchev, a deaf mute, was also called Semenishchenkov. Similarly, the family of Semen Chutskov of Tambovka village, Akhalkalaki uezd in the 1860s, being impoverished, was commonly known as Chutsenkov.

As well, the change could involve modifying both the root and suffix elements of the surname. Thus, in Troitskoye village in Akhalkalaki uezd in the 1880 s, the household of Ignaty Gorshenin (from gorshenya or 'potter') was informally known as Gorshkov (from gorshok or 'pot'). And in Slavyanka village, Elisavetpol uezd in the 1880s, the household of Semen Babakaev (from bab$a k a i$, a Tatar term for 'grandfather') was alternately known as Babanin (from babanya, a diminutive of baba or 'grandmother'). In these cases, the resulting name, while similar-sounding, was distinct in form and often in meaning.

\subsection{Re-Adoption of Extinct Surnames}

Finally, some ulichnye familii (4 of an identified sample of 275 names) arose through the re-adoption of official surnames which, over the course of the 19th century, had become extinct among the Doukhobors. This typically occurred when the male line of a family ended, and the female line assumed the defunct surname as an alternate name. For example, when Prokofy Lunin of Novo-Troitskoye village, Elisavetpol uezd, the last male member of his family, died in the 1860s, his sister's husband Gerasim Svetlichnev adopted Lunin as an informal name for his household. Thus, the continuity of an otherwise extinct surname could be secured through its use as an alternate name among matrilineal descendants.

\section{USE AND TRANSMISSION}

\subsection{Manner of Use}

Oral tradition reveals that 19th century Doukhobors freely alternated between their ulichnye familii and their official surnames. The one name was readily substituted for the other in daily conversation, and the only practical distinction between the two was their legal status. 
Indeed, it was not uncommon for Doukhobor villagers to use these alternate names almost exclusively in their informal, day to day exchanges with one another. Thus, in the 1870s, Fyodor Chernenkov of Bogdanovka village, Akhalkalaki uezd (whose ulichnaya familiya was Denisov) would have been customarily called 'Fyodor Denisov', his wife 'Anna Denisova', his son 'Nikolai Denisov', etc. by neighbours. Since everyone in the village knew each other, there was little practical need to mention his official surname, as it was common knowledge and implicitly understood. Accordingly, where Doukhobor families and clans used ulichnye familii, official surnames were largely reserved for interactions with government officials and outsiders, and for formal use in official records and legal transactions.

Occasionally, both names were used so interchangeably by a Doukhobor family group that it eventually became unclear — to both village neighbours and family members alike - as to which was the ulichnaya familiya and which the official surname. For instance, when interviewed for this article, Fyodor Atamanov, aged 66, of Slavyanka, Azerbaijan, acknowledged that his family was known as both Atamanov and Golubov, but expressed uncertainty as to which his family's original surname. Typically, this only occurred after several generations of prolonged use.

Also, some Doukhobor families were known by more than one version of an ulichnaya familiya at a time. For instance, in Slavyanka village, Elisavetpol uezd in the 1870s, the family of Arefey Verigin was known as Arekhov (from Arekha, a diminutive of the men's name Arefey) as well as Areshin (from Aresha, another diminutive of Arefey). Differing forms of these names typically involved similar-sounding variants of the same root. Within the village setting, where everyone was familiar with one another, these name variations appear to have been commonly known and understood.

Normally, ulichnye familii were defined by their common usage in a village. That is, they were mutually known by their bearers as well as by other villagers. However, this was not always strictly the case. Occasionally, an ulichnaya familiya was used by villagers in secret to denote a family who were, themselves, unaware of the name. For instance, in Slavyanka village, Elisavetpol uezd in the 1890s, the household of Anna Chernova, a rather stout woman, was known as Tolstukhin (from tolstukha or 'fat woman'), unbeknownst to the family (at the time). Similarly, in Pokrovka village, Saskatchewan in the 1900s, the household of Vasily Chernov, who was reputedly fathered by a Georgian named Kyura, was known as Kyurushkin, unbeknownst to the family (at the time). This often occurred when the ulichnaya familiya had a particularly negative or derogatory connotation.

Not surprisingly, most ulichnye familii were highly localized. Since most 19th century Doukhobors seldom ventured beyond a 10-15 kilometer radius 
from their own village, the knowledge and use of these names was restricted to a limited geographical area; typically, the immediate vicinity of their bearer's village. It was simply not necessary to differentiate between families, households and kinship groups who lived outside of this social network.

It also follows that the Doukhobor folk custom of ulichnye familii was almost entirely oral in practice. This reflects a number of factors, including the widespread illiteracy among 19th century Doukhobors; their informal use of these names in daily conversation; and the localized distribution of these names. Consequently, ulichnye familii rarely (20 of an identified sample of 275 names) appear in 19th century records. Where they co-appear with the official surname, they are often denoted by a dash ('Popov-Oseev'), by parenthesis ('Terekhov (Erokhin)'), or by the words on zhe $i$ or 'also known as' ('Bludov on zhe i Pusov').

\subsection{Frequency of Use}

It is impossible to definitively state how many ulichnye familii were actually in use by Doukhobors in the 19th century Caucasus. Clearly, not every family had one; although many did. And while the writer has identified a sample of 275 such names, there are surely many others that have been forgotten and lost over the preceding century and a half.

If we conservatively estimate that 25 percent of Doukhobor families used ulichnye familii, then based on their population of 1,097 households in the Caucasus in the year 1873, we might expect to find upwards of 275 such names (incidentally, the size of the sample identified herein) among them then. On the other hand, if we liberally estimate that upwards of 50 percent of Doukhobor families used ulichnye familii at that time, there may have been as many as 550 such names in use.

Almost certainly, the number of ulichnye familii among the Doukhobor of the Caucasus increased exponentially over time. That is, there were more such names in use among families and kin at the end of the 19th century than in the middle of that century; and still more in use by the early 20th century. This is corroborated by numerous interview subjects from Gorelovka, Georgia and Slavyanka, Azerbaijan who noted that by the Forties and Fifties, 'almost every family in the village' had an ulichnaya familiya. This stands to reason, since the need to distinguish among family groups would have increased as they multiplied and expanded over time.

\subsection{Hereditary Transmission}

A defining feature of ulichnye familii among the Doukhobors was their transmission from one generation to the next. In this respect, they generally followed 
the same lines of patrilineal descent as official surnames. That is, male and female children received both the surname and alternate name of the father; when an adult male child had children of his own, they received both names in turn; while an adult female child assumed the surname and secondary name of her husband's family when she married; and so the cycle repeated itself. It was not uncommon for ulichnye familii to be passed down through 5-7 generations of a Doukhobor family in this manner.

To illustrate, beginning in the 1840s, the household of Yakov Kalmykov (b. 1813) of Novo-Goreloye village, Elisavetopol uezd was informally known as Yashin (from Yasha, a diminutive form of his name). This ulichnaya familiya was passed on to his son Savely (b. 1843); who subsequently transferred it to his son Semen (b. 1864); Semen's son Savely (b. 1882) also received the name; which was passed on, in turn, to his son Yakov (b. 1905). Thus, by the turn of the 20th century, the family had been using this same alternate name for five generations over sixty years. Throughout this time, family members were routinely called Yashin by fellow villagers while their official surname served mainly as a clan identifier within the village social network.

On rare occasions, a Doukhobor man might take the ulichnaya familiya of his in-laws. This usually only occurred when the groom, through lack of means, went to live with his bride's parents. For example, when Vasily Savenkov moved into the household of his in-laws, the Markins, in Goreloye village, Akhalkalaki $u e z d$ in the 1850 s, he (and subsequently his children) adopted their alternate name, Maksimushkin. Similarly, when Nikolai Postnikov joined the household of his wife's family, the Bondarevs, in Slavyanka village, Elisavetpol uezd in the 1870 s, he (and later his offspring) assumed his in-laws' secondary name, Lavrov. In this manner, Doukhobor ulichnye familii were sometimes passed down through matrilineal as well as patrilineal lines.

Sometimes, after several generations, the patrilineal line of a family died out, leaving only the matrilineal line bearing an ulichnaya familiya. For instance, today, the Oslopov family (matrilineal line) of Gorelovka village, Georgia is exclusively known as Trunin, even though the name originally applied to the Smorodin family (patrilineal line).

From time to time, the descendants of a Doukhobor family (that bore an $u l$ ichnaya familiya) became so numerous that additional, new ones were formulated to distinguish between subsequent generations of the same clan. For instance, beginning in the 1840s, the family of Khrol Popov in Slavyanka village, Elisavetpol uezd was commonly known as Khrolov; by the 1880s, however, he had over 100 descendants living in the village; therefore, in order to differentiate themselves from other kin, the household of his eldest son Makar adopted an alternate name of their own, Makarov. In some cases, as many as two or 
three different ulichnye familii were adopted by subsequent generations of the same family. In many cases, the family continued to be identified by both the old name and the new one. For instance, the Markin family of Gorelovka village, Georgia was known as both Butuzov and Mikitin (or Butuzov-Mikitin) to distinguish themselves from other sub-branches of the Mikitin (Markin) family. Thus, more than one ulichnaya familiya was sometimes used to differentiate between sub-clans of a family. This process typically occurred over several generations among the more prolific Doukhobor families.

In rare instances, an ulichnaya familiya was used by only a single generation of a family and was not passed down to subsequent generations. However, this usually only occurred when the ensuing generation of the family adopted an alternate name of their own which differed from that of the preceding generation. Among the best known examples are the alternate names of the Verigin dynasty of Doukhobor leaders: Petr Vasil'evich Verigin (b. 1859) also called Gospodniy; his son Petr Petrovich Verigin (b. 1881) or Chistyakov; and his son Petr Petrovich Verigin (b. 1904) also known as Istrebov. This single-household, single-generation use of ulichnye familii would appear to be the exception rather than the norm among Doukhobors.

\subsection{Adoption as Official Surnames}

Over the course of several generations, an ulichnaya familiya might be used so extensively by a Doukhobor family group that their original surname gradually disappeared from daily use and the alternate name supplanted it entirely. In these instances ( 24 of an identified sample of 275 names), the family abandoned their official surname through attrition, as it no longer held any social relevance or practical importance in their lives. The ulichnaya familiya, in turn, assumed legal status and become official, in the standard sense.

This process did not always occur uniformly. In some cases, the alternate name was officially adopted by all family members, without exception. For instance, in Goreloye village in Akhalkalaki uezd in the 1840s, the entire family of Nikolai Tertichnikov, also called Taranov, adopted the latter name on an exclusive basis. More often, the alternate name was officially adopted by only some family members and kin. Thus, in Slavyanka village, Elisavetpol uezd in the 1870 s, of the family of Polikarp Svetlov, also known as Svetlikov, one son legally adopted the latter name, while three sons officially retained the former, while continuing to use the latter as an ulichnaya familiya.

In most cases, those Doukhobor families and clans that officially adopted their ulichnye familii did so in the last decades of the nineteenth or first decades of the twentieth century. This reflects the relative ease and informality with 
which the sectarians could change their surnames during that period, before bureaucratic record-keeping became more pervasive.

\subsection{Geographical Transmission}

While Doukhobor ulichnye familii normally had a very local distribution, they could and did sometimes relocate with their bearers from one location to another. The Doukhobors may well be unique among Russian peasants in this respect, as the existing scholarship exclusively considers ulichnye familii in fixed, solitary villages. ${ }^{7}$ This geographical transmission was made possible, in large part, by the Doukhobors' tendency to migrate and resettle en masse and not individually.

Throughout the 19th and early 20th century, Doukhobors generally relocated from one place to another in close-knit groups of extended families and kinship groups. Moreover, Doukhobors from one village tended to resettle together in the same new village. With each migration, they carried with them their beliefs, practices and traditions, which were transplanted from old settlement to new. In doing so, the Doukhobors maintained a strong social cohesion and cultural continuity, reinforced by their inherent conservatism and insularity. This settlement pattern ensured an uninterrupted connection of kin-based social networks between the original and new location. As a consequence, many folk customs, including ulichnye familii, were perpetuated from one Doukhobor village to the next.

By way of illustration, following the Russo-Turkish War of 1877-1878, several thousand Doukhobors were permitted to settle in the newly acquired territory of Kars near Russia's border with the Ottoman Empire. ${ }^{8}$ The resettlement was carried out on a village-by-village basis, with large convoys of Elisavetpol and Akhalkalaki Doukhobors journeying to Kars okrug ('administrative district') where they each established new settlements. In each new Kars village, the sectarians reproduced, as fully as possible, the cultural ethos and social fabric of the village they left behind. This invariably included many ulichnye familii from their former home. Thus, in the Kars village of Spasovka in the 1880s, for example, we find various alternate names in use that can be traced back to the Elisavetpol villages of Slavyanka and Novo-Troitskoye where their bearers originated. These include: Zhikharev (Semenov), Mikishin (Popov), Kislin (Gor'kov), Nikolenkov (Chernov), Tikhonov (Popov), Telegin (Novokshonov), Levonov (Popov), Babanin (Babakaev) and Khrolov (Popov) to name but a few.

7 Supra note 4.

8 Between 1880 and 1886, 2,770 Doukhobors relocated from Elisavetpol and Akhalkalaki uezds to Kars okrug and oblast. 
It follows that ulichnye familii could continue to be used among Doukhobor families and clans, notwithstanding their spatial dislocation and displacement.

The geographical transfer of ulichnye familii would be repeated on a much larger scale twenty years later, when Doukhobors living in the Caucasus were brought to a decision to emigrate by renewed persecution arising from their refusal to perform military service. ${ }^{9}$ To this end, with the assistance of the Quakers and Lev Tolstoy, several thousand Doukhobors sailed to Canada in $1899,{ }^{10}$ where they were granted large tracts of homestead land reserved for their use in what is now Saskatchewan; ${ }^{11}$ material aid in establishing themselves in their new country; and exemption from military duty. Upon their arrival on the Canadian prairies, they took up the land and established scores of new compact agricultural villages. ${ }^{12}$

The conditions of Doukhobor settlement in Canada in 1899 helped ensure, at least initially, the preservation and transfer of the cultural values they brought from their homeland. First and foremost, their isolated bloc settlements enabled the Doukhobors to establish themselves in a self-contained manner with minimal influence (or interference) from other settlers. At the same time, the differences between the sectarians and their host society served to reinforce their inherent sense of separateness. Additionally, the Doukhobors were able to settle together in compact villages, thus allowing them to maintain a strong social cohesion. This was enabled through the application of the 'hamlet clause' in The Dominion Lands Act by Canadian authorities, which otherwise required homesteaders to satisfy individual residency requirements. ${ }^{13}$ Through concessions in homestead policy, the Doukhobors were able to cultivate their lands communally, in a semi-feudal, open field system reminiscent of Russia, without regard for the individual cultivation duties required of homesteaders. Also, they constructed Old World villages that in physical layout and architecture, closely re-

9 See: Woodcock, G. \& Avakumovic, I. (1977). The Doukhobors. Toronto: McClelland and Stewart Limited.

${ }_{10}$ Initially, 7,459 Doukhobors came to Canada in 1899. Between then and 1912, they were joined by another 1,250 coreligionists. Approximately 12,000 Doukhobors remained in the Caucasus.

11 The Government of Canada set aside four large blocks of homestead land (750,000 acres) in the Northwest Territories (present-day Province of Saskatchewan) reserved for the Doukhobors' sole use: Tracie, C.J. (1996). 'Toil and Peaceful Life' Doukhobor Village Settlement in Saskatchewan 1899-1918. Regina: Canadian Plains Research Center.

12 Upon their arrival in Canada in 1899, the Doukhobors established 57 Old World villages; by 1905, the number had increased to 67.

${ }_{13}$ Normally, homestead entrants were required to live on the homestead quarter at least six months each year for three years in order to qualify for a patent (title) to the land. The application of the 'hamlet clause' of The Dominion Lands Act allowed the residence requirement to be fulfilled while living in a village within three miles of the homestead quarter. 
sembled those they had left behind. ${ }^{14}$ Many of these new villages were, in fact, named after their former ones in Russia. Finally, each of their new settlements was founded by extended family groups of Doukhobors who originated from the same settlement in the Caucasus, thus ensuring a substantial degree of continuity between kinship populations. And thus, the Doukhobors set about recreating a new Dukhobor'ye on the Canadian prairies.

In this socio-cultural context, it is no surprise that a substantial body of ulichnye familii were transferred by the Doukhobors from the Caucasus to Canada in 1899 , where they continued to be used as they had been for generations. Based on available oral and written sources, at least 90 such names made their way to the Canadian prairies; however, given the absence of available data, it is possible that the actual number was considerably higher. In terms of their distribution, these names are known to have occurred in at least 52 Canadian Doukhobor villages of this era; although it is reasonable to presume that they could be found in virtually every village.

The frequency of ulichnye familii in early Doukhobor settlements in Canada can be illustrated by the village of Uspeniye in the Saskatchewan Reserve. Founded by Doukhobors from Terpeniye village, Kars okrug in 1899, it initially comprised 187 Doukhobors living in 35 households. Of them, at least 7 households comprising $22 \%$ of the village population were informally known by the following alternate names: Siluanov (Kolesnikov), Katunin (Postnikov), Lavrov (Bondarev/Postnikov), Starchikov (Postnikov), Ivanov (Ivin) and Zakharushkin (Postnikov). In this case, almost a quarter of the village population continued to use ulichnye familii brought with them from Terpeniye, when referring to each other in their new Canadian environment.

Another, even more striking example is the village of Utesheniye in the Good Spirit Lake Annex, which was established by Doukhobors from Slavyanka village, Elisavetpol uezd in 1899. At that time, it was comprised of 151 Doukhobors living in 25 households. Of these, at least 11 households comprising $49 \%$ of the village population were commonly known by the following alternate names: Anisin (Petrov), Golubenkov (Golubov), Savel'ev (Strelyaev), Kutyrkin (Zhurav'lev), Efremov (Kireev) and Gerov (Gerasimov). In this case, virtually half of the village population used ulichnye familii in Canada that had originated, decades earlier, in their original village of Slavyanka.

The high incidence of ulichnye familii in some 1899-era Doukhobor villages in Canada can be further explained by the patrilocal (i.e. a couple settling in

14 In Canada, the Doukhobors initially formed villages in a linear pattern, with single family households aligned on either side of a long, central street. Known as a Strassendorf plan, this pattern was used exclusively by Doukhobors in their Molochnaya and Caucasus settlements. 
the household of the husband's father) nature of these settlements. That is to say, most Doukhobors settled in Canada in kinship groups of extended patrilineal relatives from the same village in the Caucasus. This inevitably resulted in a high proportion of related Doukhobors within the same Canadian settlements, many of whom shared the same patrilineal ancestors, official surnames and consequently, ulichnye familii, with each other.

Remarkably, the social and cultural environment of early Doukhobor settlements in Canada not only ensured the transmission and reuse of many ulichnye familii from the Caucasus; it also fostered the creation of a number of entirely new ones. For instance, in the South Reserve village of Tambovka in the 1900 s, the household of Petr Medvedev came to be unofficially known as Bozhiy ('Godly'); while the family of Mikhailo Medvedev from the same village was commonly called Uverenniy ('assured of, convinced'). In the same era, the household of Anna Verigina in the South Reserve village of Otradnoye became alternately known as Anyutushkin (from Anyutushka $<$ Anna). There were, undoubtedly, other instances of new ulichnye familii arising in early Canadian Doukhobor settlements that oral tradition has not preserved in sufficient clarity.

\section{DECLINE AND DISUSE}

Based on our understanding of ulichnye familii among 19th and early 20th century Doukhobors, it can be said that the folk custom was intrinsically rooted in their traditional settlement patterns and kinship networks.

As we have seen, Doukhobors historically settled in rural agrarian areas in small isolated villages. It was this pattern of settlement that facilitated the social relationships based on kinship and locality, interaction between individuals, concepts of family identity and shared cultural traditions upon which these names were based.

At the same time, kinship networks were historically one of the most significant factors organizing and structuring Doukhobor life. Comprised of extended family members living in close proximity, they were the basic unit of social organization within the village and were essential in the use and transmission of these names.

It was within this kin-based village structure that ulichnye familii became customary among Doukhobors as a means of differentiating and identifying village families. As long as this structure continued to be maintained, the folk custom remained a vibrant, relevant and useful part of their cultural repertoire.

\subsection{In Canada}

However, by 1905 on the Canadian prairies, the Doukhobors' traditional settlement patterns and kinship networks were under siege. 
When they took up the lands reserved for them in Saskatchewan, most Doukhobors entered for homesteads individually, but farmed them communally while living in villages. However, an influx of land-hungry settlers in the vicinity of the Doukhobor reserves and growing public backlash forced the Canadian government to withdraw the concessions it had originally granted the Russian sectarians. It now insisted that individual cultivation and residency requirements be strictly satisfied; a pledge of allegiance to the Crown be given as prerequisite to continued entry; and individual patents be applied for within prescribed deadlines. ${ }^{15} \mathrm{~A}$ homestead crisis ensued, dividing the Doukhobor community into two factions. Under mounting pressure, a third of the Doukhobors (the 'Independent Doukhobors') vacated their villages to take up residence on their individual homesteads. The remaining two-thirds (the 'Community Doukhobors') refused on religious grounds and had their homestead entries cancelled in 1907; they subsequently moved to privately purchased land in British Columbia, Alberta and elsewhere in Saskatchewan to establish new communal settlements. Consequently, by 1918, most original Doukhobor villages in Saskatchewan stood empty and abandoned.

Those Independent Doukhobors who left their villages to live on individual homesteads were among the first to relinquish ulichnye familii. With their fewer numbers, lower population densities and dispersed pattern of settlement, the social conditions that necessitated these names no longer existed among them. That is, they no longer had an immediate social need to differentiate between families with the same surnames living in the same place. Moreover, the longstanding kinship networks that sustained these names as a folk custom had been fragmented among them as a result of the division over homesteads. And while Independent Doukhobors struggled to preserve their Russian language and culture, their openness to the influences of Canadian society (i.e. public education in English schools, mixed marriages, etc.) contributed towards their eventual assimilation and integration. As a consequence, the folk custom gradually waned among them. By the 1920s and 1930s, those Independent Doukhobors who retained an affinity towards their ulichnye familii adopted them (11 names) as official surnames while the remainder slowly disappeared from daily use.

Community Doukhobors, by contrast, continued to live in villages across Western Canada for several more decades. Organized as the Christian Community of Universal Brotherhood ('CCUB'), they worked their agricultural lands in common and established various communal industrial enterprises. Given their village lifestyle, greater numbers and higher population densities, together with their iso-

${ }^{15}$ See Szalasznyj, K.R.M. (1977). The Doukhobor homestead crisis 1898-1907 (MA thesis). University of Saskatchewan, Saskatchewan; Tracie, supra note 11. 
lation and resistance to Canadian values and way of life, one might expect their use of ulichnye familii to have continued unabated. However, there were several factors that mitigated against this. First, the villages established by Community Doukhobors after 1908 differed radically from the traditional model and consisted of single or double large multi-family residences in which as many as 30 to 50 people resided. ${ }^{16}$ This new pattern of settlement effectively eliminated the single-family household as the basis of social organization amongst them; and it was this basic social unit upon which ulichnye familii were founded. Second, most CCUB villages were comprised of deliberately mixed populations of families originating from different places in the Caucasus. This redistribution of Community Doukhobor families disrupted the generations-old local kinship networks through which ulichnye familii had been maintained. This is not to suggest that Community Doukhobors did not continue to use these names; many, in fact, did. However, the folk custom never regained the prominence it once had among them, generations earlier. By the 1930s, a number of Community Doukhobor families officially adopted their ulichnye familii (10 names) as surnames. But following the dissolution of the CCUB in 1937-1939 ${ }^{17}$ and subsequent breakup of communal villages, Community Doukhobors began to assimilate and adopt Canadian culture, and the majority of these names, little by little, passed out of common use.

Today, only a small and dwindling number of Canadian Doukhobor elders in their seventies, eighties and nineties still remember the ulichnye familii that were once commonplace among their parents and grandparents.

\subsection{In the Caucasus}

A different situation emerged in the Caucasus, where despite the upheavals of war, revolution and collectivization, the isolated rural villages of the Doukhobors remained largely intact throughout the first three quarters of the 20th century. ${ }^{18}$ The relative stability of settlements and kinship networks ensured the uninterrupted continuity of ulichnye familii among local Doukhobors there. Not only did Doukhobors in Georgia and Azerbaijan preserve and maintain many of these names from the 19th century, they continuously created new ones throughout this period.

${ }_{16}$ The CCUB nucleated settlements were deliberately planned to facilitate a more communal lifestyle than traditional Doukhobor linear settlements.

17 By 1924, the CCUB was the largest communal organization in North America. However by 1937 , mounting debt, property losses and decreased membership forced it into bankruptcy and dissolution: see Woodcock and Avakumovic, supra, note 9.

18 Except for the migration of 4,500 Doukhobors to Sal'sk rayon, Rostov oblast, Russia and another 500 to Mikhailovka rayon, Zaporozh'e oblast, Ukraine in 1921-1924, the Doukhobor population in the Caucasus remained relatively stable during the first three quarters of the 20th century. 
To illustrate, out a sample of 275 ulichnye familii identified by the writer, 173 were actively used by Doukhobors in the Bogdanovka and Dmanisi rayons ('regions') of Georgia and Kedabek rayon of Azerbaijan during the early to mid-20th century. Of these, 123 names originated in the previous century, while at least 50 were coined in that century. Far from being moribund, the folk custom remained robust and continually evolving among the Caucasian Doukhobors of this period.

Perhaps inevitably, however, the depopulation of Doukhobor villages in the Caucasus began in the 1960s and continued gradually through the 1970s and 1980s. The pursuit of employment opportunities and post-secondary education, as well as the desire for warmer climates, to leave the isolated frontier, and to be among ethnic Russians all contributed to the steady outflow of Doukhobor migrants to various regions of Russia and Russian-speaking Ukraine. ${ }^{19}$ In the 1990s and 2000s, economic hardship, regional instability and ethnic tensions during the collapse of the Soviet Union drove many of the remaining Doukhobors in the Caucasus to migrate en masse to Russia. ${ }^{20}$

The unprecedented disruption and dispersal of Doukhobor settlements in the Caucasus over little more than a generation has led to a rapid breakdown of traditional values, lifestyle and social relationships among Doukhobor families living in the post-Soviet republics. This process is further hastened by the wholesale adoption of mainstream Russian culture, intermarriage, advanced education and urbanization among younger generations of Doukhobors.

Today, many Doukhobors in the post-Soviet republics in their forties, fifties or older still readily recall the ulichnye familii used in their native villages. However, they have become a nostalgic memory of times gone by and are no longer actively used among them. The present situation is perhaps best summarized by Lyubov Kalmykova, aged 54, of Gorelovka, Georgia, who observed that 'our Doukhobor customs are retreating into history; we still remember something, but our children do not know anything...'.

\section{CONCLUSION}

A longstanding folk tradition among rural peasants in Tsarist Russia, ulichnye familii were extensively adopted by Doukhobors in the Caucasus during the 1841 to

19 During this period, Doukhobors from Georgia and Azerbaijan migrated individually and in small groups to Stavropol and Rostov oblasts, Russia, Krymskaya oblast, Ukraine and elsewhere.

${ }^{20}$ In 1989-1994, 750 Doukhobors from Georgia migrated to Chern and Kamenka rayons, Tula oblast, Russia. In 1998-1999, 300 more relocated to Kletnya rayon, Bryansk oblast, Russia. Finally, in 2007-2008, 270 Georgian Doukhobors resettled to Pervomaysky rayon, Tambov oblast, Russia. Other Doukhobors migrated individually and in small groups to various regions of Russia. 
1886 period. The sectarians primarily engaged in this practice to meet a particular problem within their society: the need to distinguish among multiple households sharing the same surname in a village. Passed down to succeeding generations and transferred between settlements, ulichnye familii became a recognized form of address within Doukhobor society, helping structure kinship networks and organize social interactions among villagers. A ubiquitous part of their common culture for generations, today ulichnye familii have all but disappeared among Doukhobors, as a result of their assimilation, dispersal and modernization.

\section{REFERENCES}

Agafonov, I.S. (16.12.2017). Correspondence with the author re: Gyurdzhev (Agafonov) name. Minsk, Belarus.

Atamanov, F.A. (01.08.2017). Correspondence with the author re: Atamanov (Golubov) name. Novograd-Volinsky, Ukraine.

Barnes, A. (13.01.2019). Correspondence with the author re: Nestorov (Ozerov/Kinyakin) name. Sundre, Alberta, Canada.

Bondoreff, J.I. (1984). Ospennia "Dug-out" Hut Village 1899-1904. Bridging the Years: Era of Blaine Lake and District 1790-1980 (pp. 22-24). Blaine Lake: Town of Blaine Lake and Rural Municipality of Blaine Lake \#434.

Brandon Daily Sun (02.10.1939). New Deal for Doukhobors (p. 12). Brandon, Manitoba, Canada.

Chernoff, W. (08.07.2017). Interview with the author re: Tolstukhin (Chernov) name. Fredericton, New Brunswick, Canada.

Chernoff, F.F. (15.08.2008). Correspondence with the author re: Nikolenkov and Mikheev (Chernov) names. Winnipeg, Manitoba, Canada.

Chutskov, V.M. (22.03.2002). Correspondence with the author re: Semin and Prudnisky (Chutskov) names. Tbilisi, Georgia.

Denisoff, N.J. (01.08.2006). Interview with the author re: Denisov (Chernenkov) name. Glade, British Columbia, Canada.

Goncharov, F. (04.10.2017). Correspondence with the author re: Skvortsov (Goncharov) name. Gyumri, Armenia.

Goncharova, L.N. (18.04.2017). Correspondence with the author re: Gorelovka names. Mirnyy, Russia.

Goncharova, L.N. (2012). Malaya Sibir' - Dukhoboriya. Bryansk.

Goncharova, L. (16.05.2017). Correspondence with the author re: Maksimushkin (Markin/ Savenkov) name. Yessentuki, Russia.

Gor'kova, P. (30.08.2017). Correspondence with the author re: Tikhonov (Tarasov) and Kovalev (Tarasov) names. Dubovka, Russia.

Gubanova, M. (04.10.2017). Correspondence with the author re: Zaichikov (Tolmchaev) and Abrashin (Kalmykov/Astafurov) names. Tsvetochnoye, Russia.

Inikova, S.A. (2003). Tsena 'Tsarstva Bozh'ego' na Molochnykh Vodakh (1802-1841). Religiovedenie (No. 3). Blagoveshchensk: Izd. AmGU.

Kanigan, V. (15.06.2002). Correspondence with the author re: Telegin (Novokshonov) name. Castlegar, British Columbia, Canada.

Kalmakoff, M.S. (15.06.2007). Interview with the author re: Buchanan names. Canora, Saskatchewan, Canada. 
Kalmakoff, N.N. (1976). Kalmakoff Family History. Canora, Saskatchewan, Canada.

Kalmakoff, S.S. (1972). Correspondence with J.A. Kalmakoff re: Novo-Gorelovka Kalmykov names. Vernon, British Columbia, Canada.

Kalmykov, F.V. (01.03.2017). Correspondence with the author re: Novo-Gorelovka names. Novo-Blagodarnoye, Russia.

Kalmykov, Y. (12.01.2018). Correspondence with the author re: Kolobkov and Mairamov (Kalmykov) names. Moscow, Russia.

Kalmykova, L. (09.11.2017). Correspondence with the author re: Lunin and Mavrin (Kalmykov) names. Tula, Russia.

Kalmykova, P. (21.06.2017). Correspondence with the author re: Gorelovka, Spasovka, Orlovka and Efremovka Kalmykov names. Arkhangel'skoye, Russia.

Karnitsky, P.N. (1988). Karnitsky, Polly N. Spinning Stories: A Woven History, Kamsack, Togo, Veregin, Runnymede, Cote (pp. 509-510). Kamsack: Kamsack History Book Committee.

Konkin, J. (01.08.2014). Correspondence with the author re: Korovin (Filippov) name. Saskatoon, Saskatchewan, Canada.

Krasnikova, E. (05.02.2018). Correspondence with the author re: Efremovka names. Kommayak, Russia).

Krasnikova, T. (05.10.2017). Correspondence with the author re: Spasovka and Gorelovka names. Arkhangel'skoye, Russia.

Kuchin, V.V. (17.01.2018). Correspondence with the author re: Tselinsky names. Rostov-na-Donu, Russia.

Langham \& District History Book Committee (2007). Langham \& District History, 1907-2007. Langham, Saskatchewan.

Lapshinoff, S. (12.01.2018). Correspondence with the author re: Slepoff (Antifaeff) name. Crescent Valley, British Columbia, Canada.

Library \& Archives Canada. 1901 Census of Canada. Microfilm Reel Nos. T-6431, T-6432, T-6434, T-6552-T6554.

Library \& Archives Canada. Department of the Interior Papers. Record Group 15, Volumes 754758, File 494483; Volumes 1163-1168, Files 5391335, 5404640-5404692, 5412425-5412501, 5412973.

Library \& Archives Canada. Ship Passenger Lists, 1865-1922. Microfilm Reel Nos. C-4519, C-4542, C-4784, C-7341, T-481-T-486, T-494, T-497, T-498, T-505, T-513, T-518, T-4692, T-4699, T-4721, T-4738, T-4741, T-4744, T-4745, T-4768, T-4769, T-4774-T-4779, T-4783-T-4785, T-4787-T-4790, T-4794, T-4795, T-4823, T-14715, T-14729, T-14734, T-14746, T-14801, T-14811, T-14815, T-14816, T-14825, T-14826, T-14829, T-14931, T-15160, T-15224.

Lupina, Y. (04.10.2017). Correspondence with the author re: Soldatov (Kurbatov) name. Cherkessk, Russia.

Makaseev, N. (05.01.2018). Correspondence with the author re: Tatosov (Makaseev) name. Anapa, Russia.

Makaseeva, O. (25.10.2017). Correspondence with the author re: Tatosov (Makaseev) name. Moscow, Russia.

Makhonin, M.A. (01.11.2017). Correspondence with the author re: Gorelovka and Spasovka names. Sevastopol, Russia

Makortoff, F.F. (28.03.2018). Correspondence with the author re: Suropov (Makhortov) name. Castlegar, British Columbia, Canada.

Maloff, P.N. (1948). Dukhobortsy: Ikh istoriia, zhizn i bor'ba (North Kildonan, Manitoba: J. Regehr.

Markina, T. (19.12.2012). Correspondence with the author re: Gorelovka names. Tyumen Russia.

National Archives of Armenia. Fond 133, Opis 1, Delo 3063 and 3123.

Oslopova, T. (30.12.2017). Correspondence with the author re: Oslopov names. Tula, Russia. 
Pas'ko, M.V. (29.10.2017). Correspondence with the author re: Strelkov (Popov) name. Zernograd, Russia.

Pereverzeva, N. (17.01.2018). Correspondence with the author re: Tselinsky names. Rostov-na-Donu, Russia.

Petroff, S.J. (19.12.2002). Interview with the author re: Buchanan names. Canora, Saskatchewan, Canada.

Pirogov, N. (25.10.2018). Correspondence with the author re: Vasil'chikov (Trofimenkov) name. Cambodia.

Popoff, E.A. (15.06.1999). Correspondence with the author re: Doukhobor names. Grand Forks, British Columbia, Canada.

Popoff, E.A. (1956). Rasskazy iz Istorii Dukhobortsev. Grand Forks, British Columbia: Union of Spiritual Communities of Christ.

Popoff, E.A. (14.01.2018). Interview with the author re: Doukhobor ulichnye familii. Grand Forks, British Columbia, Canada.

Popoff, E.A. (2008). A Turbulent Century of Transition. USCC Youth Festival Booklet (Brilliant, Union of Spiritual Communities of Christ).

Popova, A. (15.06.2002). Correspondence with the author re: Dmanisi names. Moscow, Russia.

Popov, A.S. (2006). Autobiography of a Siberian Exile. E.A. Popoff (Trans.) (Kelowna, British Columbia.

Popove, M. (15.07.2017). Interview with the author re: Vakulikh (Strelyaev) name. Pass Creek, British Columbia, Canada.

Postnikoff, T.G. (1982). Childhood Recollections. Blaine Lake, Saskatchewan.

Rasskazova, N. (08.10.2016). Correspondence with the author re: Slavyanka names. Kochubeevskoye, Russia.

Reibin, S.F. (1955). Toil and Peaceful Life. Sacramento, California.

Saskatchewan Archives Board. Census of Independent Doukhobors, Microfilm Reel No. R-2.46.

Semenoff, J.J. (01.07.2005). Correspondence with the author re: Golubenkov (Golubov) name. Grand Forks, British Columbia, Canada.

Shaido, T. (25.01.2018). Correspondence with the author re: Novo-Gorelovka names. Vitebsk, Belarus.

Sherstobitov, Y.A. (22.01.2018). Correspondence with the author re: Efremovka names. St. Petersburg, Russia.

Shukin, H.P. (15.06.2001). Interview with the author re: Havrushin (Shukin) and Kurnosov names. Kamsack, Saskatchewan, Canada.

Slastukhin, V. (01.05.2016). Correspondence with the author re: Gorelovka names. Gorelovka, Georgia.

Soukeroff, J. (11.01.2019). Correspondence with the author re: Maximov name. Castlegar, British Columbia, Canada.

State Archives of the Azerbaijan Republic. Fond 10, Opis 32, Delo 10; Fond 43, Opis 2, Delo 7179 and 7352 .

State Archives of Odessa Oblast. Fond 1, Opis 219, Delo 3; Opis 151, Delo 77; Opis 152, Delo 16; Opis 153, Delo 9; Opis 154, Delo 23; Opis 166, Delo 32.

State Historical Archives of Georgia. Fond 254, Opis 2, Delo 2091; Opis 2, Delo 338; Opis 3, Delo 276; Opis 3, Delo 118, 123, 189, 191, 275, 276; Opis 3, Delo 1541, 1559, 1617, 1865, 1866, $1888,1893,1889,1892$.

Sukharev, N. (08.02.2018). Correspondence with the author re: Tselina names. Vasil'evka, Russia.

Sukhorukova, P. (04.01.2018). Correspondence with the author re: Mysin, Chuparov (Goncharov) and Aglichanov (Sukhorukov) names. Bryan'sk, Russia.

Sukhorukov, A. (10.11.2017). Correspondence with the author re: Sukhorukov names. Zheleznovodsk, Russia. 
Sukhorukov, B. (01.11.2017). Correspondence with the author re: Migralev (Sukhorukov) name. Belgorod, Russia.

Sukhorukov, V. (07.11.2017). Correspondence with the author re: Fedin (Sukhorukov) name. Tyumen, Russia.

Sulerzhitskii, L.A. (1982). To America with the Doukhobors M. Kalmakoff (Trans.). Regina, Saskatchewan: Canadian Plains Research Center, University of Regina.

Swetlow, S.C. (15.08.1998). Correspondence with the author re: Lunin (Svetlichnev) name. Vancouver, British Columbia, Canada.

Tamilin, A. (13.01.2018). Correspondence with the author re: Dudkov and Trusikov (Tamilin) names. Tambov, Russia.

Terletsky, V.I. (1911). Sekta Dukhoborov'. M.A. Kal'nev (red.). Russkie Sektanty, ix uchenie, kul't i sposevy propagandy. Odessa: E.I. Fesenko.

Vanin, J.G. and Strukoff, W.P. (1988). Doukhobor Villages. History Coming Alive: R.M. of St. Philips, Pelly and District, (pp. 10-12, Vol. 1). Pelly: St. Philips, Pelly and District History Book Committee.

Vasilenkova, S. (07.01.2017). Correspondence with the author re: Novo-Spasovka names. Kurganinsk, Russia.

Verigin, M.M. (22.07.2005). Interview with the author re: Barchukov (Kolesnikov) name. Cowley, Alberta, Canada.

Vyshlova, T. (10.10.2017). Correspondence with the author re: Gryakov and Aseev (Goncharov) names. Novopetrovsky, Russia.

Wasilenkoff, M. (24.03.2018). Correspondence with the author re: Vakulikh (Strelyaev) and Suropov (Makhortov) names. Pass Creek, British Columbia, Canada.

Zybin, V.V. (1964). 'Ispoved' Starika Dukhobortsa: Vospominaniya o Pereselenii Dukhobortsev v Kanadu. Saskatchewan Archives Board, J.A. Popoff Fonds, S-A 562).

\section{APPENDIX: AN INVENTORY OF DOUKHOBOR ULICHNYE FAMILII}

The following is an inventory of extant ulichnye familii occurring among the Doukhobors of the Caucasus and Canada during the 19th and 20th centuries. Based on extensive field interviews with Doukhobor elders in Canada, Russia, Georgia and Azerbaijan and through comprehensive archival research of Imperial Russian and Canadian records as well as published Doukhobor literature, it contains 275 names used by Doukhobor families. ${ }^{21}$ It includes, wherever possible, the corresponding official surname of the family; original head of household to which the name pertained; the settlements ${ }^{22}$ in which it occurred; and whether the name was subsequently legally adopted as an official surname. As these ulichnye familii were predominantly oral, informal and colloquial, this inventory is not and cannot be exhaustive.

${ }^{21}$ Several names in this Appendix (Andreev, Barchukov, Gerasimov, Kovalev, Larin, Lunin, Mitin, Nazarov, Nestorov, Novikov, Petrov, Seminishchev, Tikhonov, Vanin, Utkin and Zhikharev) occurred historically as both official surnames and as ulichnye familii among the Doukhobors. However, such names almost always applied to unrelated families living in different settlements and time periods.

${ }^{22}$ Saskatchewan reserves denoted as: NR (North Reserve), SR (South Reserve), GSA (Good Spirit Lake Annex) and SAR (Saskatchewan Reserve). 
ABRASHIN (Abrasha < Abram). Of the household of Abram Trofimovich Kalmykov (b. 1792) of Goreloye village, recorded in the cameral list of Akhaltsikhe uezd in 1853. Transferred to Spasskoye village in the 1920s. Also applied to Ivan Ivanovich Astafurov (b. 1904) when he was adopted into this family.

ABROSIN (Abrosya < Abrosim). Of the household of Abrosim Petrovich Abrosimov (b. 1820) of Goreloye village, recorded in the cameral list of Akhalkalaki uezd in 1873. Also applied to Abrosimov's grandson-in-law, Ivan Grigor'evich Balabanov (b. 1898) when he joined the household.

AFONIN (Afonya < Afanasy). Used by an unidentified family from Efremovka village, Akhalkalaki uezd in the late 19th century. Derived from the name of the head of household.

AGLICHANOV (aglichan < anglichan or 'Englishman'). Of the household of Nikolai Alekseevich Sukhorukov (b. 1885) of Spasskoye village, Akhalkalaki uezd. During the Russian Civil War, wartime shortages resulted in looting in the village; Sukhorukov's wife Mariya (b. 1890) caught a neighbour stealing and started a fight; the neighbour derisively called her aglichanka; at the time England was considered an enemy, having intervened against the Red Army.

AKHREMOV (Akhrem < Efrem). ${ }^{23}$ Of the household of Efrem Nikitich Gubanov (b. 1857) of Goreloye village, recorded in the family list of Akhalkalaki uezd in 1886.

ALEKSASHIN (Aleksasha < Aleksandr). Of the household of Aleksandr Tikhonovich Fofonov (b. 1812) of Novo-Troitskoye village, recorded in the cameral list of Elisavetpol uezd in 1853. Transferred to Terpeniye, Kars okrug in 1880; Vernoye (SR) and Novo-Troitskoye (GSA), Saskatchewan in 1899; and surrounding districts in 1907-1918.

ALESHKIN (Aleshka < Aleksei). Of the household of Aleksei Osipovich Uglov (b. 1850) of Orlovka village, recorded in the family list of Akhalkalaki uezd in 1886. Transferred to Efremovka village in the 1920s.

ANDREEV (Andrei). Of the household of Andrei Vasil'evich Beloivanov (b. 1887) of Slavyanka village, recorded in the family list of Elisavetpol uezd in 1908.

ANIKUSHIN (Anikusha < Anikei). Of the household of Anikei Filippovich Popov (b. 1803) of Rodionovka village, recorded in the cameral list of Akhaltsikhe uezd in 1853. Transferred to Troitskoye and Vozneseniye (NR), Saskatchewan in 1899 and surrounding district in 1912; Uspeniye (NR) in 1908; Glade and Crescent Valley, British Columbia in 1912.

ANISIN (Anisa < Anis'ya). ${ }^{24}$ Of the household of Anis'ya Petrova (b. 1795), wife of Nikita Petrovich Petrov of Slavyanka village, recorded in the cameral list of Elisavetpol uezd in 1853. Transferred to Utesheniye (GSA), Saskatchewan in 1899; and surrounding district in 1910.

ANTONOV (Anton). Used by an unidentified Lezhebokov family from Bogdanovka village, Akhalkalaki uezd in the late 19th century. Derived from the name of the head of household. Transferred to Vasil'evka, Sal'sk okrug in 1922.

ANTOSHIN (Antosha < Anton). Of the household of Anton Fedorovich Trofimenkov (b. 1875) of Spasskoye village, recorded in the family list of Akhalkalaki uezd in 1886. Transferred to Trudovoye, Sal'sk okrug in 1922.

ANYUTUSHKIN (Anyutushka $<$ Anyuta $<$ Anna) ${ }^{25}$. Of the household of Anna Vasil'evna Verigina (b. 1860) of Otradnoye village (SR), recorded in the census of Saskatchewan in 1901. Widowed

${ }_{23}$ Prior to adopting Akhremov, this family was known by the alternate name Bezborodin.

${ }_{24}$ Prior to adopting Anisin, this family was known by the alternate name Petrenkov.

25 The Doukhobor settlement Anyutushkino selo or "Anutooshkin village" in the Ootischeniya district of British Columbia (1909-1938) received its name from this family. 
twice with children and step-children from both marriages (some bearing the Podovinnikov surname and some the Semenov surname), Anyutushka cared for all of these children with great kindness and love. Because of this, her brother, Doukhobor leader Petr Vasil'evich Verigin, bestowed the name 'Anyutushkin' upon them so that they would all be identified with this matriarch. Transferred to Brilliant, British Columbia in 1912. Officially adopted by some descendants as 'Anutooshkin' in the 1920s.

AREKHOV (Arekha < Arefei). ${ }^{26}$ Also known as ARESHIN (Aresha $<$ Arefei). Of the household of Arefei Antonovich Verigin (b. 1798) of Slavyanka village, recorded in the cameral list of Elisavetpol uezd in 1853. Transferred to Blagosklonnoye (GSA), Saskatchewan in 1899 and surrounding district in 1911; and Brilliant, British Columbia in 1912. Officially adopted by some descendants as 'Arekoff' or 'Arehoff' in the 1920s.

ARININ (Arina < Irina). Of the household of Irina Kalmykova (b. 1829), widow of Timofey Petrovich Kalmykov of Goreloye village, recorded in the family list of Akhalkalaki uezd in 1886. Transferred to Efremovka village in the 1920s.

ARININ (Arina < Irina). Of the household of Irina Agafonova (b. 1860), wife of Andrei Alekseevich Agafonov of Slavyanka village, recorded in the family list of Elisavetpol uezd in 1908.

ARKHIPOV (Arkhip). Of the household of Arkhip Semenovich Savenkov (b. 1787) of Ormasheni village, recorded in the cameral list of Tiflis uezd in 1853. Transferred to Bashkichet village in 1909.

ASKYAROV (askyar or 'soldier' in Turkic) ${ }^{27}$ Of the household of Vasily Vasil'evich Filippov (b. 1892) of Slavyanka village, recorded in the family list of Elisavetpol uezd in 1935. Filippov served in the Azerbaijan Soviet Socialist Republic army and was thus nicknamed askyar by his Azeri neighbours in the village.

ATAMANOV (ataman or 'chief', 'leader'). Of the household of Vasily Ivanovich Golubov (b. 1832) of Slavyanka village, recorded in the cameral list of Elisavetpol uezd in 1860. From the 1860 s to 1880 s, Golubov was ataman of the local Doukhobor Cossacks that patrolled and safeguarded the village from robbers and bandits. Officially adopted by descendants in the 1920s.

BABAKOV (babaka< baba or 'grandmother'). Of the household of the widow Anna Petrovna Ungloved (b. 1816) of Orlovka village, recorded in the family list of Akhalkalaki uezd in 1886. The family received this name because it was headed by this grandmother. Transferred to Goreloye village in 1894.

BABANIN (babanya $<$ baba or 'grandmother'). Of the household of Semen Fedoseevich Babakaev (b. 1833) of Slavyanka village, recorded in the cameral list of Elisavetpol uezd in 1873. The family was sometimes known by this similar-sounding name. Transferred to Spasovka, Kars okrug in 1880; Spasovka (SAR), Saskatchewan in 1899; Gromovoye (NR) in 1906; and Ootischenia, British Columbia in 1912.

BARABULIN (barabul'ya or 'red mullet' fish). ${ }^{28}$ Of the household of Nikolai Petrovich Sukhorukov (b. 1925) of Goreloye, Georgia. Sukhorukov was nicknamed 'barabul'ya' as a youngster.

BARCHUKOV. Of the household of Kirill Grigor'evich Kolesnikov (b. 1820) of Slavyanka village, recorded in the cameral list of Elisavetpol uezd in 1853. Barchukov (barchuk< barin or 'nobleman') was the maiden name of his wife Mariya (b. 1820), which became extinct in the male line

${ }^{26}$ The Doukhobor settlement Arekhovo selo or "Arekhoff village" in the Winlaw district of British Columbia (1912-1938) received its name from this family.

27 Prior to adopting Askyarov, this family was known by the alternate name Churukov.

${ }^{28}$ Prior to adopting Barabulin, this family was known by the alternate name Mikhailin. 
of her family. ${ }^{29}$ Transferred to Terpeniye, Kars okrug in 1880; Uspeniye (SAR), Saskatchewan in 1899; Brilliant, British Columbia in 1912.

BARYCHKIN (borychka < borych or 'pepper' in Turkic). Of the household of Kondrat Fedorovich Chuchmaev (b. 1833) of Goreloye village, recorded in the cameral list of Akhalkalaki uezd in 1873. Chuchmaev was nicknamed borychka, presumably because he grew, ate or traded in peppers.

BEZBORODIN (bezboroda or 'beardless'). Of the household of Nikifor Nikitich Gubanov (b. 1786) of Goreloye village, recorded in the family list of Melitopol uezd in 1845. Gubanov or a forebear received the nickname bezboroda presumably because he did not wear a beard in the Old Russian style. Transferred to Goreloye, Akhalkalaki uezd in 1845.

BOZHIY ('Godly'). ${ }^{30}$ Of the household of Petr Ivanovich Medvedev (b. 1860) of Tambovka village (SR), recorded in the village census of Saskatchewan in 1905. This name was bestowed upon Medvedev by Doukhobor leader Petr Vasil'evich Verigin because of his outstanding faith and belief. Transferred to Perry Siding, British Columbia in 1912; and Cowley, Alberta in 1916. Officially adopted as 'Bojey' by family members in the 1920 s.

BURBALEV (burbal or 'bubble'). Of the household of Fyodor Ivanovich Vasilenkov (b. 1862) of Slavyanka village, recorded in the family list of Elisavetpol uezd in 1908. Most likely, Vasilenkov was teasingly given the dialect nickname burbal as a young child.

BUTUZOV (butuz or 'chubby child', 'kiddy'). ${ }^{31}$ Of the household of Dmitry Semenovich Markin (b. circa 1915) of Goreloye, Akhalkalaki uezd. In all likelihood, Markin was playfully given the nickname butuz as a youngster.

CHISTYAKOV (chistyak or 'cleanser', 'purger'). ${ }^{32}$ Of the household of Petr Petrovich Verigin (b. 1881), leader of the Middle Party Doukhobors in Russia from 1906 to 1927 and the Community Doukhobors in Canada from 1927 to 1939. This name was bestowed upon Verigin by his followers in Russia and Canada in the 1920s, who believed he was destined to delineate what was an authentic understanding of Doukhobor principles from what was not.

CHULKOV (chulok or 'sock', 'stocking'). Of the household of Savely Antonovich Kazakov (b. 1830) of Orlovka village, recorded in the cameral list of Akhalkalaki uezd in 1873. Kazakov was nicknamed chulok presumably because of the stockings he made or wore. Transferred to Vera (NR), Saskatchewan in 1899; and surrounding district in 1910.

CHUPUROV (chupur or 'pockmarked' in Turkic). ${ }^{33}$ Of the household of Dmitry Ivanovich Goncharov (b. circa 1890) of Goreloye village, Akhalkalaki uezd. Goncharov received this Turkic nickname, presumably because he matched this physical description.

29 The last male member of the original Doukhobor family, Akim Vasil'evich Barchukov (b. 1768), died in Spasskoye village, Melitopol uezd in the 1840s.

${ }^{30}$ The Doukhobor settlement Bozhoye selo or "Bojey village" in the Cowley district of Alberta (1916-1938) and Bojey Road in Perrys, British Columbia received its name from this family.

${ }^{31}$ Prior to adopting Butuzin, this family was known by the alternate name Mikitin. The lane known as Butuzov pereulok in Gorelovka, Tiflis (Georgia) was named after this family.

32 The Doukhobor settlement Chistyakovka in the Tselina district of Rostov oblast, Russia (1921-) and the settlement area Chistyakovo or Chistyakovka in the Grand Forks district of British Columbia (1937-1943) were named after this ulichnaya familiya.

33 Prior to adopting Chupurov, this family was known by the alternate name Gryakov. 
CHURUKOV (churuk or 'cigar'). ${ }^{34}$ Of the household of Semen Ivanovich Filippov (b. 1832) of Slavyanka village, recorded in the cameral list of Elisavetpol uezd in 1873. Filippov received the dialect nickname churuk, probably because he often smoked cigars.

CHUTSENKOV. Of the household of Semen Andreevich Chutskov (b. 1812) of Tambovka village, recorded in the cameral list of Akhaltsikhe uezd in 1853. Impoverished compared to other households, the Chutskov (chutkiy or 'sharp of hearing') family was sometimes known by this diminutive form of their surname.

CHYORIKOV (chyorik < chyor or 'black'). Used by an unidentified Smorodin family from Goreloye village, Akhalkalaki uezd in early 20th century. Derived from the nickname chyorik, given to a head of household with black hair or eyes or dark, swarthy features.

DARIN (Dar'ya). Of the household of Dar'ya Popova (b. 1819), widow of Stepan Danilovich Popov of Slavyanka village, recorded in the cameral list of Elisavetpol uezd in 1860. Transferred to Terpeniye, Kars okrug in 1880; Terpeniye (SAR), Saskatchewan in 1899; and surrounding district in 1905. Officially adopted as 'Dargin' by some descendants in the 1920s.

DENISOV (Denis). Of the household of Denis Vasil'evich Chernenkov (b. 1798) of Bogdanovka village, recorded in the cameral list of Akhaltsikhe uezd in 1853. Transferred to Lebedevo (NR), Saskatchewan in 1899; Glade, British Columbia in 1912; Vasil'evka, Sal'sk okrug in 1922. Officially adopted as 'Denisoff' or 'Denisow' by some descendants in the 1920s.

DENNIKAREV (dennikar or 'horse stall keeper'). Of the household of Leon Kireev (b. circa 1780) of Troitskoye village, recorded in the family list of Melitopol uezd in 1844. Kireev or a forebear probably kept or tended a dennik ('horse stall') in a stable, hence this archaic occupational name. Transferred to Slavyanka, Elisavetpol uezd in 1844.

DETOCHKIN (detochkoy < detka or 'little child', 'kiddy'). Of the household of Vasily Ivanovich Tomilin (b. 1940) of Goreloye village, Georgia. Tomilin's parents called him detochkoy for a long time, which became his nickname in adulthood.

DOBROV (dobryi or 'good'). Used by an unidentified Bludov family from Bashkichet village, Borchali uezd in the late 19th and early 20th centuries. Derived from the nickname dobryi, given to a head of household, presumably because he was a kind, sensitive, good-natured person.

DOBRYNIN (Dobrynya). Of the household of Gavrila Tikhonovich Tikhonov (b. circa 1770) of Terpeniye, Melitopol uezd. An army deserter, Tikhonov hid among his coreligionists under forged documents bearing this name, presumably derived from the name of a mid-18th century progenitor.

DONGAROV (dongar or 'hunchbacked' in Turkic). ${ }^{35}$ Of the household of Fyodor Ivanovich Filippov (b. 1905) of Slavyanka village, recorded in the family list of Elisavetpol uezd in 1935. Filippov's wife was hunchbacked, and thus acquired the nickname dongar from her Azeri neighbours.

DUDKOV (dudok or 'pipe', 'horn'). Of the household of Ivan Tikhonovich Tomilin (b. 1932) of Goreloye, Georgia. Tomilin was nicknamed dudok as a youngster because of his loud, booming voice.

DUKHOBOROV (dukhobor or 'spirit wrestler'). Of the household of Minai Grigor'evich Ipakin (b. 1778) of Efremovka village, Melitopol uezd. An escaped serf, Ipakin hid among his coreligionists under forged documents bearing this name, derived from his adherence to the Doukhobor faith.

${ }^{34}$ Prior to adopting Churukov, this family was known by the alternate name Korovin.

${ }^{35}$ Prior to adopting Dongarov, this family was known by the alternate name Koroninsky. 
DUNIN (Dunya < Evdok'ya). Of the household of Evdok'ya Ivanovna Agafonova (b. 1897), wife of Ivan Andreevich Agafonov of Slavyanka village, recorded in the family list of Elisavetpol uezd in 1935 .

EFIMOV (Efim). Of the household of Efim Alekseevich Rybalkin (b. 1862) of Novo-Goreloye village, recorded in the family list of Elisavetpol uezd in 1886.

EFREMOV (Efrem). ${ }^{36}$ Of the household of Efrem Leonovich Kireev (b. 1795) of Slavyanka village, recorded in the cameral list of Elisavetpol uezd in 1853. Transferred to Utesheniye (GSA), Saskatchewan in 1899; and Brilliant, British Columbia in 1918.

EFREMOV (Efrem). Of the household of Petr Grigor'evich Evdokimov (b. 1790) of Rodionovka village, recorded in the cameral list of Akhaltsikhe uezd in 1853. Efrem was presumably the name of a mid-18th century ancestor. Transferred to Vossianye (SR), Saskatchewan in 1899; Yorkton, Saskatchewan in 1912; and Brilliant, British Columbia in 1918.

EROKHIN. Of the household of Mikhail Anisimovich Terekhov (b. 1831) of Goreloye village, recorded in the cameral list of Akhalkalaki uezd in 1873. It may derive from either the name of an 18 th century ancestor (Erokha $<$ Erofei) or from the dialect nickname erokha, meaning 'stubborn', 'slovenly' or 'disheveled'.

ESIN (Esya < Iosif). Of the household of Iosif Iosifovich Vyshlov (b. circa 1780) of Efremovka village, recorded in the family list of Melitopol uezd in 1845. Transferred to Novo-Goreloye, Elisavetpol uezd in 1847. The name was also applied to Vyshlov's grandson-in-law, Evdokim Pavlovich Rybalkin (b. 1834) when he joined the household.

EVREICHIKOV (evreichik or 'Jew'). Of the household of Vasily Matveyevich Savenkov (b. 1832) of Orlovka village, recorded in the cameral list of Akhalkalaki uezd in 1873. Savenkov was nicknamed evreichik because he was considered greedy, enterprising and cunning; racial stereotypes commonly associated with Jews in Russia during that period. Transferred to the neighbouring village of Goreloye in 1894.

EVSIN (Evsei). Of the household of Evsei Il'ich Konkin (b. 1783) of Slavyanka village, recorded in the cameral list of Elisavetpol uezd in 1853. Transferred to Otradnoye (SR), Saskatchewan in 1905; and Brilliant, British Columbia in 1912.

EVSIN (Evsei). Used by an unidentified Trofimenkov family from Spasskoye village, Akhalkalaki uezd in the late 19th century. Derived from the name of the head of household. Transferred to Trudovoye, Sal'sk okrug in 1922.

FEDIN (Fedya < Fyodor). Of the household of Fyodor Ivanovich Kazakov (b. 1801) of Orlovka village, recorded in the cameral list of Akhaltsikhe uezd in 1853. Transferred to Terpeniye and Voskriseniye (SR), Saskatchewan in 1899; Petrovo (SR) in 1912; and surrounding districts in 1912-1918.

FEDIN (Fedya < Fyodor). Of the household of Fyodor Ivanovich Sukhorukov (b. 1830) of Goreloye village, recorded in the family list of Akhalkalaki uezd in 1886.

FEDOSEEV (Fedosei). Of the household of Fedosei Alekseevich Kalmykov (b. 1812) of Novo-Goreloye village, recorded in the cameral list of Elisavetpol uezd in 1860.

FEDOTOV (Fedot). Belonging to the household of Fedot Petrovich Lezhebokov (b. 1893) of Bogdanovka village, recorded in the family list of Akhalkalaki uezd in 1895. Transferred to Vasil'evka, Sal'sk okrug in 1922.

${ }^{36}$ Prior to adopting Efremov, this family was known by the alternate name Dennikarev. 
FEDULOV (Fedula < Fyodor). Of the household of Fyodor Stepanovich Zubkov (b. 1830) of Rodionovka village, recorded in the cameral list of Akhalkalaki uezd in 1873. Transferred to Vasil'evka, Sal'sk okrug in 1922.

FINASHIN (Finasha < Finogen). Also known as FINASOV (Finas < Finogen). Of the household of Finogen Vasil'evich Kalmykov (b. 1797) of Novo-Goreloye village, recorded in the cameral list of Elisavetpol uezd in 1853. Transferred to Novo-Goreloye (GSA) and Besednoye (SR), Saskatchewan in 1899 and surrounding districts in 1907; Blagoveshcheniye (SR) in 1908; and Cowley, Alberta in 1915 .

FROLOV (Frol). Of the household of Frol Zbitnev (b. circa 1760) of Kirilovka village, recorded in the family list of Melitopol uezd in 1841. Transferred to Goreloye, Akhalkalaki uezd in 1841; Novo-Spasskoye, Elisavetpol uezd in 1847; Gorelovka, Kars okrug in 1880; Slavnoye (SR), Novo-Spasskoye (GSA) and Malaya Gorelovka (SAR), Saskatchewan in 1899; surrounding districts in 1907-1912.

GARASOV (garas < zaras or 'now'). ${ }^{37}$ Of the household of Nikolai Ignat'evich Sukhorukov (b. 1962) of Goreloye village, Georgia. Sukhorukov had a speech impediment and slurred his words; he was nicknamed garas because of how he mispronounced the word zaras.

GAVRUSHIN (Gavrusha $<$ Gavrila). Also known as HAVRUSHIN (Havrusha $<$ Havrila $<$ Gavrila). Of the household of Gavrila Vasil'evich Shchukin (b. 1845) of Novo-Troitskoye village, recorded in the family list of Elisavetpol uezd in 1880. Transferred to Kirilovka, Kars okrug in 1880; Vernoye (SR), Saskatchewan in 1899; and surrounding district in 1911.

GERASIMOV (Gerasim). Also known as GARASIN (Garasya M < Gerasim). Of the household of Gerasim Prokof'evich Kalmykov (b. 1814) of Novo-Goreloye village, recorded in the cameral list of Elisavetpol uezd in 1853.

GEROV (Gerya < Gerasim). Of the household of Stepan Alekseevich Gerasimov (b. 1829) of Slavyanka village, recorded in the cameral list of Elisavetpol uezd in 1860. Transferred to Utesheniye (GSA), Saskatchewan in 1899; Brilliant, British Columbia in 1912.

GOLOVKOV (golovka < golova or 'head'). Of the household of Ivan Vasil'evich Strelyaev (b. 1888) of Slavyanka village, recorded in the family list of Elisavetpol uezd in 1935. Strelyaev may have received the nickname golovka because he was clear and astute, as the head of a household or leader, or because he had a prominent head on a slender neck.

GOLUBENKOV. Of the household of Marfa Golubova (b. 1825), widow of Vasily Ivanovich Golubov of Slavyanka village, recorded in the cameral list of Elisavetpol uezd in 1873. Widowed young with small children and little means of livelihood, Golubova (golub or 'dove') was known by this diminutive surname. Transferred to Otradnoye (SR) and Utesheniye (GSA), Saskatchewan in 1899 and surrounding districts in 1911; Brilliant, British Columbia in 1912.

GONCHARIK. Of the household of Mikhail Petrovich Goncharov (b. 1947) of Goreloye village, Georgia. The family was known by this diminutive form of their surname to distinguish them from other Goncharov (gonchar or 'potter') households.

GORLOV (gorlo or 'throat'). Of the household of Il'ya Dmitrovich Bykanov (b. 1776) of Rodionovka village, recorded in the family list of Melitopol uezd in 1841. Bykanov may have been nicknamed gorlo because he had a loud voice or shout. Transferred to Rodionovka, Akhalkalaki uezd in 1841; Terpeniye (SR) village, Saskatchewan in 1899; Grand Forks, British Columbia in 1912.

GORSHKOV (gorshok or 'pot'). Of the household of Ignat Fedorovich Gorshenin (b. 1846) of Rodionovka village, recorded in the cameral list of Akhalkalaki uezd in 1873. The family was

${ }^{37}$ Prior to adopting Garasov, this family was known by the alternate name Mikhailin. 
sometimes known by this similar-sounding name, derived from the same root as their official surname (gorshenya or 'potter'). Transferred to Vera (NR), Saskatchewan in 1899; and Semenovo (NR) in 1908.

GOSPODNIY ('of the Lord'). Of the household of Petr Vasil'evich Verigin (b. 1859), leader of the Large Party Doukhobors in the Caucasus from 1887 to 1899 and the Community Doukhobors in Canada from 1899 to 1924. This name was bestowed upon Verigin by his followers in Canada in the 1910s, who saw him as a living embodiment of Christ-like ideals and virtues in this world.

GRUNIN (Grunya < Agrafena). Also known as HRUNIN (Hrunya < Agrafena). Of the household of Agrafena Sherstobitova (b. 1817), widow of Nikolai Fedotovich Sherstobitov of Efremovka village, recorded in the cameral list of Akhalkalaki uezd in 1863.

GRYAKOV (gryak or 'mud', 'grime' or 'sludge'; gryaka or 'hot' or 'heat'). Of the household of Ignaty Petrovich Goncharov (b. 1816) of Goreloye village, recorded in the cameral list of Akhaltsikhe uezd in 1853. Goncharov was nicknamed gryak or gryaka because he somehow embodied this quality.

GURLYOV (gurli < gusi or 'geese'). Of the household of Aleksei Mikhailovich Vlasov (b. 1916) of Goreloye village, Georgia. As a child, Vlasov would exclaim gurli! (a mispronunciation of gusi whenever he saw geese in the village, hence the nickname.

GYURDZHEV (gyurdzhyu or 'Georgian' in Georgian). Of the household of Semen Semenovich Agafonov (b. 1883) of Slavyanka village, recorded in the family list of Elisavetpol uezd in 1908. Agafonov was so nicknamed because he was the only one in his village able to speak and understand the Georgian language.

IGNATOV (Ignat). Of the household of Ignat Egorovich Kalmykov (b. 1814) of Novo-Goreloye village, recorded in the cameral list of Elisavetpol uezd in 1860. Transferred to Gorelovka, Kars okrug in 1880; Malaya Gorelovka (SAR), Saskatchewan in 1899; Arkhangel'skoye (NR) in 1906; and Shoreacres, British Columbia in 1912.

ILYUNIN (Il'yunya < Il'ya). Of the household of Il'ya Nikiforovich Pryamorukov (b. 1835) of Goreloye village, recorded in the family list of Akhalkalaki uezd in 1886.

ILYUSHIN (Il'yusha < Il'ya). Of the household of Il'ya Alekseevich Markov (b. 1846) of Novo-Goreloye village, recorded in the family list of Elisavetpol uezd in 1886.

ISHCHENKOV (Ishchenka < Ishka < Ivan). Of the household of Ivan Timofeevich Samoylov (b. 1850) of Bashkichet village, recorded in the family list of Borchali uezd in 1886.

ISTREBOV (istrebitel' or 'to annihilate'). Of the household of Petr Petrovich Verigin (b. 1904), who was proclaimed the leader of Community Doukhobors in Canada in 1939 but never assumed the role due to his detainment and death in a Soviet prison camp. This name was bestowed upon Verigin by his followers in Canada in the 1920s, who believed he would abolish all false churches and destroy deceivers.

IVANOV (Ivan). Applied to the household of Grigory Gavrilovich Ivin (b. 1846) of Slavyanka village, recorded in the cameral list of Elisavetpol uezd in 1860. The family was sometimes known by this variant name derived from the same root as their surname (Iva < Ivan). Transferred to Terpeniye, Kars okrug in 1880; Uspeniye (SAR), Saskatchewan in 1899; and Brilliant, British Columbia in 1912.

IVLIEV (Ivlii). Of the household of Ivlii Nikitich Krygin (b. 1776) of Orlovka village, recorded in the cameral list of Akhaltsikhe uezd in 1853. Transferred to Efremovka (SR), Saskatchewan in 1899; Uspeniye (NR) in 1908; and surrounding district in 1913.

KAIZEROV (kaizer or 'kaiser'). Of the household of Semen Fedorovich Makhortov (b. 1883) of Grand Forks, recorded in the census of British Columbia in 1911. In the Teens, Makhortov over- 
saw communal Doukhobor operations in the district. A strict disciplinarian with a quick temper, he was likened to the autocratic Kaiser Wilhelm II of Germany, who was then at war with England and Russia; hence the nickname kaizer.

KALENSKY (of or associated with a kalenka or 'stove'). Of the household of Savely Matveevich Voykin (b. 1813) of Spasskoye village, recorded in the cameral list of Akhalkalaki uezd in 1863. Voykin acquired this name because he lived or worked near a stove. Transferred to the neighbouring village of Efremovka in 1864; Efremovka (SR), Saskatchewan in 1899.

KALICHOV (kalich or 'cripple'). ${ }^{38}$ Of the household of Mikhail Petrovich Evdokimov (b. 1826) of Rodionovka village, recorded in the cameral list of Akhalkalaki uezd in 1873. Evdokimov was nicknamed kalich, presumably because he had some form of disability. Transferred to Troitskoye (NR) and Vossianiye (SR), Saskatchewan in 1899; Yorkton, Saskatchewan in 1912; Brilliant and Grand Forks, British Columbia in 1918.

KARABAEV (karabay or 'rich proprietor' in Turkic). Of the household of Stepan Sergeevich Borisenkov (b. 1832) of Novo-Spasskoye village, recorded in the family list of Elisavetpol uezd in 1886. A wealthy farmer, Borisenkov was nicknamed karabay by his Azeri neighbours.

KARABEKOV (karabek or 'rich lord', 'strong, formidable host' in Turkic). Of the household of Andrei Alekseevich Agafonov (b. 1858) of Slavyanka village, recorded in the family list of Elisavetpol uezd in 1908. Agafonov was a prosperous farmer who received the nickname karabek from his Azeri neighbours.

KARAIVANOV (kara or 'strong', 'rich' or 'black' in Turkic + Ivan). Of the household of Ivan Goncharov (b. 1854) of Ormasheni village, recorded in the family list of Borchali uezd in 1886. Goncharov received the hybrid Turkic-Russian name Karaivan from his Azeri neighbours perhaps because of his dark features, his strength or his wealth. Transferred to Bashkichet village in 1909.

KARTOPOV (kartop or 'potatoe'). Of the household of Petr Alekseevich Agafonov (b. 1885) of Slavyanka village, recorded in the family list of Elisavetpol uezd in 1908. Agafonov received the dialect nickname kartop as a market gardener who counted and sold potatoes by the piece.

KASHKOV (kashka $<$ kasha or 'porridge'). Used by an unidentified Obed'kov family from Bashkichet village, Borchali uezd in the late 19th century. Derived from the nickname kashka, given to a head of household who presumably made or ate porridge as a meal.

KATUNIN (Katunya < Katya < Ekaterina). ${ }^{39}$ Of the household of Ekaterina Postnikova (b. 1845), wife of Ivan Zakharovich Postnikov of Terpeniye, Kars okrug, recorded in the passenger list of 1899. Transferred to Uspeniye (SAR), Saskatchewan in 1899; Slavyanka (SAR) in 1902; Brilliant and Champion Creek, British Columbia in 1912.

KHROLOV (Khrol < Frol). Of the household of Frol Popov (b. circa 1780) of Troitskoye village, recorded in the family list of Melitopol uezd in 1844. Transferred to Slavyanka, Elisavetpol uezd in 1844; Terpeniye and Spasovka, Kars okrug in 1880; Besednoye (SR), Slavnoye (SR), Nadezhda (SR), Moiseyevo (GSA), Saskatchewan in 1899; Pavlovo (NR) in 1905; and surrounding districts from 1905-1914.

KHROLOV (Khrol < Frol). ${ }^{40}$ Of the household of Frol Efimovich Sukhorukov (b. 1871) of Goreloye village, recorded in the family list of Akhalkalaki uezd in 1886.

KHROMUSHOV (khromusha $<$ khromoy or 'lame'). Used by an unidentified Miroshnikov family from Spasskoye village, Akhalkalaki uezd in the late 19th century. Derived from the nickname

38 Prior to adopting Kalichov, this family was known by the alternate name Efremov.

39 Prior to adopting Katunin, this family was known by the alternate name Zakharushkin.

${ }^{40}$ Prior to adopting Khrolov, this family was known by the alternate name Mikhailin. 
khromusha, given to a head of household who walked with a limp because of some illness or infirmity.

KHUTORSKY (of or from Khutor). ${ }^{41}$ Of the household of Anna Chernova (1858) of Khutor village (SR), Saskatchewan, recorded in the census of 1921. The family was distinguished from other Chernov families by this name because they resided in Khutor village from 1912 to 1939.

KHVENYATKIN (Khvenyatka $<$ Fenyatka $<$ Fenya $<$ Fedosiya). Of the household of Fedosiya D'yakova (b. 1915), widow of Mikhail Vasil'evich D'yakov of Bashkichet village, Georgia. D'yakova was widowed at a young age with small children when her husband was killed in the Great Patriotic War in 1943.

KHVOROSTYANOV (khvorost or 'brushwood'). ${ }^{42}$ Of the household of Aleksei Alekseevich Fofonov (b. 1862) of Novo-Goreloye village, recorded in the family list of Elisavetpol uezd in 1886. Presumably, Fofonov was nicknamed khvorost because he gathered and used brushwood for fire-making.

KISLIN (kislii or 'sour', 'tart'). Of the household of Ivan Alekseevich Gor'kov (b. 1810) of Novo-Spasskoye village, recorded in the cameral list of Elisavetpol uezd in 1873. Gor'kov was nicknamed kislii presumably because he embodied this quality in some way. Transferred to Terpeniye and Spasovka, Kars okrug in 1880; Nadezhda (SR), Spasovka (SR) and Smireniye (SR), Saskatchewan in 1899 and surrounding districts in 1911; Grand Forks and Brilliant, British Columbia in 1912-1918.

KOLOBKOV (kolobok or 'round ball of dough'). ${ }^{43}$ Of the household of Vasily Vasil'evich Kalmykov (b. 1963) of Goreloye village, Georgia. As a child, Kalmykov was short and fat and was thus teasingly nicknamed kolobok.

KOLYUSOV (Kolyusya < Nikolai). ${ }^{44}$ Of the household of Nikolai Vasil'evich Popov (b. 1853) of Bogdanovka village, recorded in the cameral list of Akhalkalaki uezd in 1873. Transferred to Semenovo (NR), Saskatchewan in 1899; Glade, British Columbia in 1912.

KONDRATOV (Kondrat). ${ }^{45}$ Of the household of Kondrat Ivanovich Konygin (b. 1822) of Slavyanka village, recorded in the cameral list of Elisavetpol uezd in 1873.

KONFORKIN (konforka or 'spirit lamp'). Used by an unidentified D'yakov family from Bashkichet village, Borchali uezd in the late 19th century. Derived from the nickname konforka, given to a head of household who presumably made or used a spirit lamp for lighting.

KONOVALOV (konoval or 'horse doctor'). Used by an unidentified family from Akhalkalaki uezd and transferred to the North Reserve, Saskatchewan in 1899. The family received this name because the head of household treated and cared for horses for disease and injuries, birthing and gelding.

KORMILUSHKIN (kormilushka < kormilets or 'provider'). Of the household of Semen Kuz'mich Savenkov (b. 1870) of Slavyanka village, recorded in the family list of Elisavetpol uezd in 1908. Orphaned at a young age and married 3 times (twice to widows with children), Savenkov was nicknamed kormilushka because his household included many stepchildren and relatives, all of whom

${ }^{41}$ Prior to adopting Khutorsky, this family was known by the alternate name Tolstukhin.

42 Prior to adopting Sitnikov, this family was known by the alternate name Frolov.

43 Prior to adopting Kolobkov, this family was known by the alternate name Lunin.

44 Prior to adopting Kolyusov, this family was known by the alternate name Nikolenkov.

${ }^{45}$ The spring known as Kondratovsky rodnik in Slavyanka, Elisavetpol (Azerbaijan) was named after this family. 
he helped provide for. Transferred to Sal'sk okrug, Rostov oblast in 1921; Langham district, Saskatchewan in 1928; and Thrums, British Columbia in 1928.

KORONINSKY (of or associated with the korona or 'crown'). ${ }^{46}$ Of the household of Fyodor Ivanovich Filippov (b. 1905) of Slavyanka village, recorded in the family list of Elisavetpol uezd in 1935. Most likely, Filippov was given this fanciful nickname because he was a proud and important person and not because of any actual association with the Russian crown.

KOROVIN (korova or 'cow'). Of the household of Ivan Moiseevich Filippov (b. 1807) of Slavyanka village, recorded in the cameral list of Elisavetpol uezd in 1860. Filippov was nicknamed korova because he and his sons owned a large herd of cows. Transferred to Slavnoye (SR) and Blagosklonnoye (GSA), Saskatchewan in 1899 and surrounding districts in 1911; Champion Creek, British Columbia in 1912.

KOSTIKOV (Kostik $<$ Kostya $<$ Konstantin). Of the household of Konstantin Erastovich Salykin (b. 1822) of Slavyanka village, recorded in the cameral list of Elisavetpol uezd in 1860. Transferred to Kirilovka, Kars okrug in 1880; Pokrovka (SAR), Saskatchewan in 1899 and surrounding district in 1905; Thrums, British Columbia in 1912.

KOVALEV (koval or 'blacksmith'). Of the household of Nikolai Evseevich Tarasov (b. 1875) of Slavyanka village, recorded in the family list of Elisavetpol uezd in 1908. Nikolai, and subsequently his son Grigory, worked as village blacksmiths, hence the name.

KOZLOV (kozel or 'billy goat'). ${ }^{47}$ Of the household of Semen Ivanovich Goncharov (b. 1796) of Novo-Goreloye village, recorded in the cameral list of Elisavetpol uezd in 1853. Goncharov was nicknamed kozel, presumably because he possessed some characteristic of a goat, such as stubbornness, orneriness or friskiness. Transferred to Staro-Goreloye (GSA), Saskatchewan in 1899; and surrounding district in 1907.

KOZLOV ( $k$ ozel or 'billy goat'). Used by an unidentified family from Borchali uezd. Derived from the nickname kozel, given to the head of household who somehow resembled a billy goat. The name was also applied to son-in-law Vasily Vasil'evich Chernov (b. 1864) when he joined the household. Transferred to Novo-Pokrovka, Kars okrug in 1886; Prokuratovo (SR), Saskatchewan in 1899; Ubezhdeniye (SR) in 1905; surrounding district in 1909.

KRAYNIY ('end', 'last', 'uttermost', 'outside'). ${ }^{48}$ Of the household of Vasily Vasil'evich Rybalkin (b. circa 1900) of Novo-Goreloye village, Elisavetpol uezd. Rybalkin was nicknamed krayniy because the family lived on the furthest outskirts of the village.

KRIVOPALOV (krivopalyi or 'crooked fingers'). Used by an unidentified Kuchin family from Troitskoye village, Akhalkalaki uezd in the late 19th century. Derived from the nickname krivopalyi, given to a head of household who matched this physical description. Transferred to Vasil'evka, Sal'sk okrug in 1922.

KRIVTSOV (krivets or a 'curved', 'disabled' or 'disfigured' person). Of the household of Petr Petrovich Goncharov (b. 1875) of Goreloye village, recorded in the family list of Akhalkalaki uezd in 1886. Goncharov's face was slashed by a sword when Turkish troops occupied his village during the Great Patriotic War in 1918; he was called krivets because of his large, disfiguring scar.

KRYLOV (krylo or 'wing'). Of the household of Nikita Evteevich Kuchin (b. circa 1780) of Troitskoye village, Melitopol uezd. An army deserter, Kuchin hid among his coreligionists under forged

${ }^{46}$ Prior to adopting Koroninsky, this family was known by the alternate name Churukov.

47 The gulley known as Kozlovaya balka near Novo-Goreloye, Elisavetpol (Azerbaijan) was probably named after this family.

${ }^{48}$ Prior to adopting Krayniy, this family was known by the alternate name Ul'yashin. 
documents bearing this name. Presumably, he was nicknamed krylo, which had the religious connotation of 'angel wings'.

KUKANOV (kukan or 'frog'). Of the household of Vasily Kuz'mich Oslopov (b. 1884) of Efremovka, Akhalkalaki uezd. Once, Oslopov fell into a river while crossing a bridge; as the current was strong and he was wearing a heavy coat, he floated (like a frog) for some distance before he was dragged out. He thus received the dialect nickname kukan. Transferred to Bogdanovka in 1894 and Goreloye in the 1920s.

KUKANOV (kukan or 'fishing rope'). Of the household of Semen Efimovich Dement'ev (b. 1834) of Bashkichet village, recorded in the cameral list of Borchali uezd in 1873. Dement'ev was probably nicknamed kukan because he and his sons were fishermen who made and used rope to string fish caught in the nearby rivers.

KULININ (Kulina < Akilina). Of the household of Akilina Evdokimovna Tomilina (b. 1815), widow of Ivan Osipovich Tomilin of Goreloye village, recorded in the cameral list of Akhalkalaki uezd in 1863 .

KURNOSOV (kurnosyi or 'snub-nosed'). Used by an unidentified family from Elisavetpol uezd and transferred to Kars okrug in 1880. The family received this nickname, presumably because of a forebear who matched this physical description.

KUTYRKIN (kutyrka or 'glutton', 'greedy eater'). Of the household of Andrei Ustinov Zhurav'lev (b. 1839) of Slavyanka, recorded in the family list of Elisavetpol uezd in 1886. Zhurav'lev or a forebear received the dialect nickname kutyrka, presumably because of this trait. Transferred to Utesheniye (GSA), Saskatchewan in 1899; and surrounding district in 1910.

KUVALYOV (kuval< koval or 'blacksmith'). Of the household of Timofei Nikolaevich Vlasov (b. circa 1895) of Goreloye village, Akhalkalaki uezd. Vlasov worked in the village as a blacksmith, repairing iron by hand, hence the dialect occupational term. Transferred to Petrovka, Sal'sk okrug in 1922.

KUZIN (Kuzya < Kuz'ma). Of the household of Kuz'ma Akimovich Sherstobitov (b. 1793) of Efremovka, recorded in the cameral list of Akhaltsikhe uezd in 1853. Transferred to Vera (NR) and Efremovka (SR), Saskatchewan in 1899; Ootischenia and Winlaw, British Columbia in 1912; and Brandon Manitoba in 1912. Officially adopted as 'Koozen' by some descendants in the 1920s.

KUZ'MOV (Kuz'ma). ${ }^{49}$ Of the household of Kuz'ma Strelyaev (b. circa 1770) of Spasskoye village, recorded in the family list of Melitopol uezd in 1844. Transferred to Slavyanka, Elisavetpol uezd in 1844; Terpeniye, Kars okrug in 1880; Vernoye (SR) and Terpeniye (SAR), Saskatchewan in 1899; and surrounding districts in 1907-1912.

KYURUSHKIN (Kyurushka < Kyura). Also known as KYURIN (Kyura). According to tradition, Anna (b. 1857), wife of Konstantin Vasil'evich Chernov of Pokrovka village, Kars okrug was raped by a Georgian. The child born as a result of this incident, Vasily (b. 1890), was nicknamed Kyurush$k a$ after his biological father, whose Georgian name Kyura means 'eagle'. Transferred to Pokrovka village (SR), Saskatchewan in 1899; Spasovka (SR) in 1907; surrounding district in 1911; Grand Forks, British Columbia in 1943.

LAPTEV (lapot' or 'bast shoe'). Of the household of Savely Petrovich Skachkov (b. 1830) of Bashkichet village, recorded in the cameral list of Borchali uezd in 1873. Skachkov or a forebear received the nickname lapot' presumably because he made or wore shoes woven from bast fiber.

49 The gulley known as Kuz'mov klin near Slavyanka, Elisavetpol (Azerbaijan) was probably named after this family. 
LARIN (Larya $<$ Larion). Of the household of Larion Petrovich Smorodin (b. 1866) of Novo-Goreloye village, recorded in the family list of Elisavetpol uezd in 1886.

LAVROV (Lavra < Lavrentii). Of the household of Lavrentii Nikiforovich Bondarev (b. 1798) of Slavyanka village, recorded in the cameral list of Elisavetpol uezd in 1853. The name was also applied to Bondarev's son-in-law Nikolai Vasil'evich Postnikov (b. 1859) when he joined the household. Transferred to Terpeniye, Kars okrug in 1882; Uspeniye (SAR), Saskatchewan in 1899 and surrounding district in 1920; Perekhodnoye (NR) in 1906; and Brilliant, British Columbia in 1913. Officially adopted as 'Loveroff' by some descendants in the 1910s.

LAZUNIN (Lazunya < Lazya < Lazar). Of the household of Lazar Danilovich Ryl'kov (b. 1794) of Tambovka village, recorded in the cameral list of Akhaltsikhe uezd in 1853. Transferred to Karabulakh, Borchali uezd in 1847; Orlovka, Akhalkalaki uezd in 1852; Tambovka (SR), Saskatchewan in 1899 and surrounding district in 1911; Winlaw, British Columbia in 1911.

LEKSIN (Leksa $<$ Aleksei or Aleksandr). Of the household of either Aleksei Fedorovich Obedkov (b. 1854) or his brother Aleksandr Fedorovich Obedkov (b. 1860) of Novo-Spasskoye village, recorded in the family list of Elisavetpol uezd in 1886.

LEKSIN (Leksa < Aleksei). Of the household of Aleksei Egorovich Chuchmaev (b. 1874) of Goreloye village, recorded in the family list of Akhalkalaki uezd in 1886.

LEVONOV (Levon < Leon). Of the household of Leon Potapovich Popov (b. 1804) of Novo-Troitskoye village, recorded in the cameral list of Elisavetpol uezd in 1853. Transferred to Spasovka, Kars okrug in 1880; Pozirayevka (SAR) in 1899 and surrounding district in 1908; Prins-Albertskoye (SR) in 1907; Brilliant, British Columbia in 1912.

LEVONOV (Levon < Leon). Of the household of Leon Sevast'yanovich Yuritsin (b. 1790) of Troitskoye village, recorded in the cameral list of Akhaltsikhe uezd in 1853. Transferred to Vasil'evka, Sal'sk okrug in 1922.

LIPATOV (lipet' or 'to adhere to', 'to be linked'). Of the household of Trofim Semenovich Kalmykov (b. 1849) of Troitskoye village, recorded in the family list of Akhalkalaki uezd in 1886. In the 1860 s, Kalmykov left his father's household in Orlovka to live with his in-laws, the Kabatov family of Troitskoye, to which he became attached; hence the dialect nickname lipet'.

LIPATOV (Lipat < Ipatii). Of the household of Ipatii Nosov (b. circa 1765) of Terpeniye village, recorded in the family list of Melitopol uezd in 1841. Transferred to Orlovka, Akhalkalaki uezd in 1841; Petrovka, Sal'sk okrug in 1922.

LIZAVETSKY (of or from Elisavetpol). Of the household of Ivan Stepanovich Kalmykov (b. 1840) of Goreloye village, recorded in the cameral list of Akhalkalaki uezd in 1873. Kalmykov acquired this name because he moved to Elisavetpol uezd (colloquially known as Lizavetpol) in 1847 but returned to the village in 1868 .

LOSKUTOV (loskut or 'rag', 'patch', 'flap', 'snippet'). Of the household of Dmitry Raspopov (b. circa 1770) of Terpeniye village, Melitopol uezd. Raspopov or a forebear was nicknamed loskut, presumably because he traded in scraps, or wore clothes made from them.

LUNIN. Of the household of Gerasim Svetlichnov (a. 1785) of Rodionovka village, recorded in the family list of Melitopol uezd in 1845. Lunin (lun or 'kestrel' or else Lunya < Luk'yan) was the maiden name of his wife Aksinya (b. 1785); which, after became extinct in the male line of her family. ${ }^{50}$ Transferred to Novo-Troitskoye, Elisavetpol uezd in 1845; Kirilovka, Kars okrug in 1880;

${ }^{50}$ The last male member of the original Doukhobor family, Prokofy Dmitrievich Lunin (b. 1796), died in Novo-Troitskoye village, Elisavetpol uezd in the 1850s. 
Kirilovka (GSA) and Pokrovka (SAR), Saskatchewan in 1899; Vozvysheniye (SR) in 1902; surrounding districts in 1907.

LUNIN (Lunya < Luker'ya). ${ }^{51}$ Of the household of the widow Luker'ya Vasil'evna Kalmykova (b. 1866) of Goreloye village, Georgia who in 1941 at the age of 75, took in her great-grandchildren after her grandson Petr Nikolayevich Kalmykov died in the Great Patriotic War.

LYOKSIN (Lyoksa < Aleksandr). Of the household of Aleksandr Ivanovich Kalmykov (b. 1817) of Goreloye village, recorded in the cameral list of Akhalkalaki uezd in 1873.

LYOSIN (Lyosya < Aleksandr). Of the household of Aleksandr Yakovlevich Tomilin (b. 1830) of Goreloye village, recorded in the family list of Akhalkalaki uezd in 1886. Transferred to Spasskoye in the 1920s.

MAIRAMOV (Mairam). ${ }^{52}$ Of the household of Mikhail Kuz'mich Kalmykov (b. circa 1952) of Goreloye village, Georgia. Kalmykov was somehow associated with an Armenian from his village named Mairam. He thus received this Armenian men's name (derived from the Biblical name 'Mary') as a nickname.

MAKAROV (Makar). ${ }^{53}$ Of the household of Makar Frolovich Popov (b. 1806) of Slavyanka village, recorded in the cameral list of Elisavetpol uezd in 1853. Transferred to Terpeniye, Kars okrug in 1880; Petrovka (SAR), Nadezhda and Vernoye (SR) in 1899; and surrounding districts in 1912; Ootischenia and Shoreacres, British Columbia in 1912. Officially adopted as 'Makaroff' by some descendants in the 1910s.

MAKSIMOV (Maksim). Of the household of Maksim Leontyevich Agafonov (b. 1802) of Slavyanka village, recorded in the cameral list of Elisavetpol uezd in 1853.

MAKSIMUSHKIN (Maksimushka < Maksim). Of the household of Maksim Ivanovich Markin (b. 1792) of Goreloye village, recorded in the cameral list of Akhaltsikhe uezd in 1853. The name was also applied to Markin's grandson-in-law, Vasily Ivanovich Savenkov (b. 1830) when he joined the household.

MALUSHKIN (malushka < mala or 'small'). Of the household of Ivan Alekseevich Agafonov (b. 1884) of Slavyanka village, recorded in the family list of Elisavetpol uezd in 1935. Diminutive in stature, Agafonov was affectionately called malushka by his first wife Mavra.

MANYUKHIN (Manyukha < Mariya).$^{54}$ Of the household of Mariya Agafonova (b. 1894), second wife of Ivan Alekseevich Agafonov of Slavyanka village, recorded in the family list of Elisavetpol uezd in 1935.

MARISHIN (Marisha < Marina). Of the household of Marina Tsybulkina (b. 1796), widow of Nikolai Trofimovich Tsybulkin of Spasskoye village, recorded in the cameral list of Akhalkalaki uezd in 1863.

MAVRIN (Mavra). ${ }^{55}$ Of the household of Mavra Kalmykova (b. 1794), widow of Egor Kalmykov of Goreloye village, recorded in the family list of Melitopol uezd in 1845. Transferred to Goreloye, Akhalkalaki uezd in 1845; and Spasskoye village in the 1920s.

51 Prior to adopting Lunin, this family was known by the alternate name Mavrin.

52 Prior to adopting Mairamov, this family was known by the alternate name Lisovetsky.

53 Prior to adopting Makarov, this family was known by the alternate name Khrolov. Makaroff Lake near Blaine Lake, Saskatchewan, Makaroff Road in Saskatoon, Saskatchewan and the Doukhobor settlement area Makarovo or Makarovka in the Castlegar district of British Columbia (1931-1938) were all named for this family.

${ }^{54}$ Prior to adopting Manyukhin, this family was known by the alternate name Malushkin.

55 The lane known as Mavrin pereulok in Gorelovka, Tiflis (Georgia) was named after this family. 
MAZHOROV (mazhor or 'major key', 'cheerful'). Of the household of Vasily Dmitrievich Deminov (b. 1916) of Goreloye village, Georgia. Always cheerful and high-spirited, Deminov was nicknamed mazhor by his neighbours.

MICHURIN (michur or a 'gloomy, silent person'). Of the household of Petr Ivanovich Nichvolodov (b. 1850) of Slavyanka village, recorded in the family list of Elisavetpol uezd in 1935. Nichvolodov received the dialect nickname michura presumably because of his personality and disposition.

MIGRALEV (Migral'). ${ }^{56}$ Of the household of Aleksei Stepanovich Sukhorukov (b. 1884) of Goreloye village, recorded in the family list of Akhalkalaki uezd in 1886. After quarrelling with a local Azeri named Migral', Sukhorukov received this Turkic men's name (meaning 'friend of Allah') as a nickname. Transferred to Spasskoye village in the 1920s.

MIKHAILIN (Mikhail). ${ }^{57}$ Of the household of Mikhail Mikhailovich Sukhorukov (b. 1797) of Goreloye village, recorded in the cameral list of Akhalkalaki uezd in 1863.

MIKHEEV (Mikhei). Of the household of Mikhei Savel'evich Chernov (b. 1803) of Slavyanka village, recorded in the cameral list of Elisavetpol uezd in 1853. Transferred to Terpeniye, Kars okrug in 1880; Petrovka (SAR), Saskatchewan in 1899 and surrounding district in 1905; Sovetnoye (SR) in 1899 and surrounding district in 1918.

MIKIN. Of the household of Vasily Danilovich Mitin (b. 1835) of Slavyanka village, recorded in the cameral list of Elisavetpol uezd in 1873. The family was sometimes known by this similar-sounding name to distinguish it from other Mitin (Mitya $<$ Dmitry) households. Transferred to Kirilovka, Kars okrug in 1880; Pokrovka (SAR), Saskatchewan in 1899; surrounding district in 1911. Officially adopted by descendants as 'Meakin' in the 1920s.

MIKISHIN (Mikisha < Mikifor < Nikifor). Of the household of Nikifor Grigor'evich Popov (b. 1792) of Troitskoye village, recorded in the family list of Melitopol uezd in 1844. Transferred to Slavyanka, Elisavetpol uezd in 1845; Spasovka, Kars okrug in 1880; Troitskoye (SAR), Saskatchewan in 1899; surrounding district in 1905. Officially adopted as 'McKishen' by some descendants in the 1920s.

MIKITIN (Mikita < Nikita). Of the household of Nikita Fedotovich Markin (b. 1804) of Orlovka village, recorded in the cameral list of Akhaltsikhe uezd in 1853. Transferred to Goreloye village in 1891.

MIRONOV (Miron). Of the household of Miron Miroshnikov (b. circa 1750) of Spasskoye village, recorded in the family list of Melitopol uezd in 1842. Transferred to Spasskoye, Akhalkalaki uezd in 1842; Slavyanka, Elisavetpol uezd in 1847; Troitskoye (SR), Saskatchewan in 1899. Officially adopted by some descendants in the 1880 s.

MISHKOV (Mishka < Misha < Mikhail). ${ }^{58}$ Of the household of Mikhail Vasil'evich Gubanov (b. 1845) of Goreloye village, recorded in the cameral list of Akhalkalaki uezd in 1873.

MITROV (Mitra < Dmitry). Also known as MITIN (Mitya < Dmitry). Of the household of Dmitry Alekseevich Kalmykov (b. 1816) of Novo-Goreloye village, recorded in the cameral list of Elisavetpol uezd in 1860. Transferred to Novo-Goreloye (GSA), Saskatchewan in 1899; Vozvysheniye (SR) in 1902; Moiseyevo (GSA) in 1908; surrounding district in 1907-1913.

56 Prior to adopting Migralev, this family was known by the alternate name Mikhailin.

57 The lane known as Mikhailin pereulok in Gorelovka, Tiflis (Georgia) was named after this family.

${ }_{58}$ Prior to adopting Mishkov, this family was known by the alternate name Bezborodin. 
MYSIN (Mysa < Moisei). Of the household of Moisei Stepanovich Smorodin (b. 1852) of Goreloye village, recorded in the family list of Akhalkalaki uezd in 1886. The name was also applied to Smorodin's son-in-law, Petr Ivanovich Goncharov (b. 1885) when Smorodin went to live in his household.

NATAL'IN (Natal'ya). Of the household of the widow Natal'ya Stepanovna Ryl'kova (b. 1892) of Novo-Goreloye village, Elisavetpol uezd. Ryl'kova was widowed young with small children and little means of livelihood.

NATALOV (Natal'ya). Of the household of Natal'ya Ivanovna Maslova (b. 1869), wife of Fyodor Fedorovich Maslov of Bogdanovka village, recorded in the family list of Akhalkalaki uezd in 1886. Transferred to Vera (NR), Saskatchewan in 1899; Ootischenia, British Columbia in 1911.

NAZAROV (Nazar). Of the household of Nazar Sergeevich Ryl'kov (b. 1805) of Terpeniye village, recorded in the family list of Melitopol uezd in 1843. Transferred to Novo-Goreloye, Elisavetpol uezd in 1847.

NEMAKHOV (nemakh or 'mute', 'dumb'). Of the household of Ivan Anan'evich Malakhov (b. 1795) of Terpeniye village, recorded in the family list of Melitopol uezd in 1843. Malakhov suffered from this speech disorder and was thus nicknamed nemakh. Transferred to Slavyanka, Elisavetpol uezd in 1843.

NESTOROV (Nestor). Of the household of Nestor Ilarionovich Ozerov (b. 1783) of Spasskoye village, recorded in the cameral list of Akhaltsikhe uezd in 1853. Also applied to his step-sons Ivan (b. 1839) and Vasily (b. 1841) Grigor'evich Kinyakin.

NIKISHIN (Nikisha < Nikifor). Of the household of Nikifor Nikolaevich Pryamorukov (b. 1869) of Goreloye village, recorded in the family list of Akhalkalaki uezd in 1886. Transferred to Efremovka village in 1894 .

NIKITIN (Nikita). Of the household of Nikita Filippovich D'yakov (b. 1803) of Efremovka village, recorded in the family list of Melitopol uezd in 1841. Transferred to Troitskoye, Akhalkalaki uezd in 1841; Ormasheni, Borchali uezd in 1847; Rodionovka (SR), Saskatchewan in 1899; and surrounding district in 1911.

NIKITIN (Nikita). ${ }^{59}$ Of the household of Nikita Efremovich Kalmykov (b. 1896) of Novo-Goreloye village, recorded in the family list of Elisavetpol uezd in 1900.

NIKOLENKOV (Nikolen'ka < Nikolai). Also known as MIKOLENKOV (Mikolen'ka < Mikola $<$ Nikolai). Of the household of Nikolai Chernov (b. circa 1720) of Bogdanovka village, recorded in the family list of Melitopol uezd in 1844. Transferred to Bogdanovka, Akhalkalaki uezd in 1844; Slavyanka, Elisavetpol uezd in 1847; Kirilovka, Spasovka and Pokrovka, Kars okrug in 1880-1886; in 1899 to Lebedevo, Lyubomirnoye and Pokrovskoye (NR); Kapustino, Novoye, Prokuratovo, Smireniye, Spasovka and Vernoye (SR); Petrovka, Spasovka, Terpeniye (SAR); and surrounding districts in 1905-1912; Perekhodnoye (NR), Saskatchewan in 1906; and Grand Forks, Ootischenia, Brilliant, Glade, Crescent Valley and Winlaw, British Columbia in 1908-1912.

NOVIKOV. ${ }^{60}$ Of the household of Grigory Semenovich Chernov (b. 1813) of Bogdanovka village, recorded in the cameral list of Akhaltsikhe uezd in 1853. Novikov (novik or 'novice', 'newcomer') is thought to be the maiden name of his wife Mar'ya (b. 1812) which became extinct in the male

59 Prior to adopting Nikitin, this family was known by the alternate name Paramonov.

${ }^{60}$ Prior to adopting Novikov, this family was known by the alternate name Nikolenkov. 
line of her family. ${ }^{61}$ Transferred to Lebedevo (NR), Saskatchewan in 1899; and surrounding district in 1912.

OSEEV (Osya < Iosif). Also known as ASEEV (Asya < Iosif). Of the household of Iosif Grigor'evich Popov (b. 1795) of Troitskoye village, recorded in the family list of Melitopol uezd in 1844. Transferred to Slavyanka, Elisavetpol uezd in 1844; Otradnoye (SR), Saskatchewan in 1899 and surrounding district in 1918; Troitskoye (SAR) in 1899; Thrums, British Columbia in 1912.

OSEEV (Osya $<$ Iosif). Also known as ASEEV (Asya $<$ Iosif). ${ }^{62}$ Of the household of Iosif Yakovlevich Goncharov (b. 1881) of Goreloye village, recorded in the family list of Akhalkalaki uezd in 1886. Transferred to Efremovka village in the 1900s.

OSEEV (Osya < Iosif). Also known as ASEEV (Asya < Iosif). Of the household of Iosif Mikhailovich Vyshlov (b. 1823) of Efremovka village, recorded in the cameral list of Akhalkalaki uezd in 1873.

PANFERKOV (Panferka $<$ Panfer $<$ Parfen). Also known as PANFEROV (Panfer $<$ Parfen). Of the household of Ivan Pavlovich Parfenkov (b. 1805) of Slavyanka village, recorded in the cameral list of Elisavetpol uezd in 1853. The family was sometimes known by these similar-sounding names derived from the same root as their surname (Parfenka $<$ Parfen). Transferred to Slavnoye (SR), Saskatchewan in 1899; and surrounding district in 1907.

PANFEROV (Panfer < Parfen). Of the household of Parfen Zotovich Antyufeev (b. 1788) of Bashkichet village, recorded in the cameral list of Tiflis uezd in 1853.

PANFEROV (Panfer < Parfen). Of the household of Parfen Ivanovich Kuchin (b. 1868) of Troitskoye village, recorded in the family list of Akhalkalaki uezd in 1886. Transferred to Vasil'evka, Sal'sk okrug in 1922.

PARAMONOV (Paramon). ${ }^{63}$ Of the household of Paramon Ivanovich Kalmykov (b. 1843) of Novo-Goreloye village, recorded in the family list of Elisavetpol uezd in 1886.

PAVLOV (Pavel). Of the household of Pavel Grigor'evich Khudyakov (b. 1884) of Novo-Goreloye, recorded in the family list of Elisavetpol uezd in 1886.

PETRENKOV. Of the household of Nikita Petrovich Petrov (b. 1793) of Spasskoye village, recorded in the family list of Melitopol uezd in 1844. Deemed poor compared to other households, the family was sometimes known by this diminutive form of their surname (Petr). Transferred to Slavyanka, Elisavetpol uezd in 1844.

PETROV (Petr). Of the household of Petr Ivanovich Pryamorukov (b. 1733) of Goreloye village, recorded in the family list of Melitopol uezd in 1842. Transferred to Goreloye, Akhalkalaki uezd in 1842.

PLATONOV (Platon). ${ }^{64}$ Of the household of Platon Dmitrievich Astafurov (b. 1810) of Novo-Goreloye village, recorded in the cameral list of Elisavetpol uezd in 1853. Transferred to Goreloye, Akhalkalaki uezd in 1857; and Troitskoye village in 1894.

PODOMAREV (podomar < ponomar or 'sexton'). Of the household of Sergei Ponomarev (b. circa 1760) of Terpeniye village, recorded in the family list of Melitopol uezd in 1842. The family

${ }^{61}$ The last male member of the original Doukhobor family, Timofey Klimovich Novikov (b. 1818), died in Bogdanovka village, Akhalkalaki uezd in the 1850s.

${ }_{62}$ Prior to adopting Oseev or Aseev, this family was known by the alternate name Gryakov.

${ }_{63}$ Prior to adopting Paramonov, this family was known by the alternate name Vanin.

${ }^{64}$ The gorge known as Platonovo ushchel'e near Novo-Goreloye, Elisavetpol (Azerbaijan) and the yard known as Platonov dvor in Gorelovka, Tiflis (Georgia) were named after this family. 
was sometimes known by this similar-sounding name (derived from the same root) to distinguish it from other Ponomarev households. Transferred to Tambovka, Akhalkalaki uezd in 1843-1844; Ormasheni, Borchali uezd in 1847; Pokrovka, Kars okrug in 1886; Blagodarnoye and Trudolyubovoye (SR), Saskatchewan in 1899. Officially adopted by descendants as 'Podmaroff' in the 1910s.

PODOVSKY. Of the household of Stepan Podovinnikov (b. circa 1775) of Bogdanovka village, recorded in the family list of Melitopol uezd in 1844. The family was sometimes known by this similar-sounding name to distinguish it from other Podovinnikov (pod or 'under' + ovin or 'threshing barn'). Transferred to Bogdanovka, Akhalkalaki uezd in 1844; Slavyanka, Elisavetpol uezd in 1847; Troitskoye, Akhalkalaki uezd in 1863; Novo-Pokrovka, Kars okrug in 1887; Petrovka (SAR), Saskatchewan in 1899. Officially adopted by some descendants as 'Padowsky' in the 1910s.

POLTINOV (poltina or 'half a ruble'). Used by an unidentified Bludov family from Bashkichet village, Borchali uezd in the late 19th century. Derived from the nickname poltina, given to a head of household who somehow came to be associated with this coin.

POVALYAEV (povalyat or 'to knock down', 'tumble' or 'to roll about'). Of the household of Anton Goncharov (b. circa 1770) of Tambovka village, recorded in the family list of Melitopol uezd in 1844. Goncharov or a forebear was nicknamed povalyat, presumably because of this action or behavior. Transferred to Orlovka, Akhalkalaki uezd in 1844. Officially adopted by descendants in the $1850 \mathrm{~s}$.

PREZIDENTOV (prezident or 'president'). Of the household of Nikolai Mikhailovich Plotnikov (b. 1879) of Grand Forks, recorded in the census of British Columbia in 1921. In 1935, Plotnikov was elected President of the Christian Community of Universal Brotherhood Ltd. until its demise in 1939. He thus became known by this occupational name.

PRONIN (Pronya < Prokofy). Of the household of Prokofy Vasil'evich Tarasov (b. 1803) of Slavyanka village, recorded in the cameral list of Elisavetpol uezd in 1860. Transferred to Terpeniye, Kars okrug in 1880; Terpeniye (SAR) in 1899; and Veregin, Saskatchewan in 1907.

PRUDNISKY (of or associated with a prudnii or 'pond', 'dam' or 'embankment'). Of the household of Nikolai Andreevich Chutskov (b. 1808) of Tambovka village, recorded in the cameral list of Akhaltsikhe uezd in 1853. Chutskov acquired this name because he or a forebear lived near such a landscape feature. Transferred to Trudolyubovoye (SR), Saskatchewan in 1899; and surrounding district in 1909.

PUGOSOV (Pugos < Pogos) ${ }^{65}$ Of the household of Vladimir Kuz'mich Oslopov (b. 1958) of Goreloye village, Georgia. Oslopov was somehow associated with an Armenian from his village named Pogos. He thus received this Armenian men's name (meaning 'boy' or 'teenager') as a nickname.

PUSOV (Pusya < Pavel). Of the household of Pavel Kirilovich Bludov (b. 1823) of Bashkichet village, recorded in the cameral list of Tiflis uezd in 1853. Transferred to Tambovka, Akhalkalaki uezd in 1863; Orlovka, Akhalkalaki uezd in 1873; Tambovka and Terpeniye (SR), Saskatchewan in 1899; and surrounding district in 1918.

RADISTOV (radist or 'radio operator'). ${ }^{66}$ Of the household of Fyodor Ivanovich Agafonov (b. 1909) of Slavyanka village, Elisavetpol uezd. During the Great Patriotic War of 1941-1945, Agafonov was a radio operator on the Soviet front in Novorossiya on the Black Sea.

${ }_{65}$ Prior to adopting Pugosov, this family was known by the alternate name Kukanov.

${ }^{66}$ Prior to adopting Radistov, this family was known by the alternate name Malushkin. 
RODIONOV (Rodion) ${ }^{67}$ Of the household of Rodion Polikarpovich Svetlov (b. 1820) of Slavyanka village, recorded in the cameral list of Elisavetpol uezd in 1860.

SANATOV (sanat or 'grace', 'greatness' or 'appearance' in Turkic) ${ }^{68}$ Of the household of Vasily Vasil'evich Strelyaev (b. 1865) of Slavyanka village, recorded in the family list of Elisavetpol uezd in 1908. Strelyaev was nicknamed sanat by his Azeri neighbours, presumably because he somehow embodied this quality.

SAVEL'EV (Savely). Of the household of Aleksei Arkhipovich Savenkov (b. 1815) of Tambovka village, recorded in the cameral list of Akhaltsikhe uezd in 1853. Savely was presumably the name of a mid-18th century ancestor.

SAVEL'EV (Savely). ${ }^{69}$ Of the household of Savely Kuz'mich Strelyaev (b. 1803) of Slavyanka village, recorded in the cameral list of Elisavetpol uezd in 1853. Transferred to Utesheniye (GSA), Saskatchewan in 1899; Kalmakovo (GSA) in 1908; and surrounding district in 1910.

SAVIN (Sava < Savely). Of the household of Savely Grigor'evich Khudyakov (b. 1870) of Novo-Goreloye, recorded in the family list of Elisavetpol uezd in 1886.

SAVINOV (Savin). Of the household of Andrei Romanovich Kozlachkov (b. 1799) of Troitskoye village, recorded in the family list of Melitopol uezd in 1844. Savin was presumably the name of a mid-18th century progenitor. Transferred to Slavyanka, Elisavetpol uezd in 1844.

SAVRASOV (savras or 'simple, working horse'). Used by an unidentified Trofimenkov family from Spasskoye village, Akhalkalaki uezd in the late 19th century. Derived from the nickname savras, given to a head of household who had many horses or who worked hard like a horse. Transferred to Trudovoye, Sal'sk okrug in 1922.

SEMENISHCHENKOV. Of the household of Prokofy Agafonovich Semenishchev (b. 1825) of Slavyanka village, recorded in the cameral list of Elisavetpol uezd in 1860. Deaf and mute, Semenishchenkov was considered a poor unfortunate and was sometimes known by this diminutive form of his surname (Semenishche $<$ Semen).

SEMENISHCHEV (Semenishche $<$ Semen).$^{70}$ Of the household of Semen Leonovich Popov (b. 1820) of Novo-Troitskoye village, recorded in the cameral list of Elisavetpol uezd in 1873. A giant of a man, Popov was known by the augmentative form of his name, Semenishche. Transferred to Spasovka, Kars okrug in 1880; Pozirayevka (SAR) in 1899 and surrounding district in 1908; Prins-Albertskoye (SR) in 1907; Brilliant, British Columbia in 1912.

SEMENYUTENKOV. Of the household of Semen Vasil'evich Semenyutin (b. 1813) of Goreloye village, recorded in the cameral list of Akhalkalaki uezd in 1863. Semenyutin (Semenyuta $<$ Semen) was less well-to-do than most householders and was sometimes known by this diminutive form of his surname.

SEMIN (Sema < Semen). Of the household of Semen Alekseevich Agafonov (b. 1861) of Slavyanka village, recorded in the family list of Elisavetpol uezd in 1886.

SEMIN (Sema < Semen). ${ }^{71}$ Of the household of Semen Andreevich Chutskov (b. 1812) of Tambovka village, recorded in the cameral list of Akhalkalaki uezd in 1863.

${ }^{67}$ Prior to adopting Rodionov, this family was known by the alternate names Svetlikov and Svetlichkov.

${ }^{68}$ Prior to adopting Sanatov, this family was known by the alternate name Savel'ev.

${ }_{69}$ Prior to adopting Savel'ev, this family was known by the alternate name Kuz'mov.

70 Prior to adopting Semenishchev, this family was known by the alternate name Levonov.

${ }^{71}$ Prior to adopting Semin, this family was known by the alternate name Chutsenkov. 
SERELOV (serel or 'grey'). Used by an unidentified Trofimenkov family from Spasskoye village, Akhalkalaki uezd in the late 19th century. Derived from the nickname serel, given to a head of household with grey hair, eyes or whiskers.

SERGEEV (Sergei). ${ }^{72}$ Of the household of Sergei Vasil'evich Strelyaev (b. 1854) of Slavyanka village, recorded in the family list of Elisavetpol uezd in 1886.

SHAMSHURIN (shamshura or 'lisper'). Also known as SHAMRIKOV (shamrit' or 'to lisp'). Of the household of Nikolai Savinovich Shustov (b. 1804) of Troitskoye village, recorded in the family list of Melitopol uezd in 1844. Shustov or a forebear received the dialect nickname shamshura or shamrik, because of this speech impediment. Transferred to Slavyanka, Elisavetpol uezd in 1844; Troitskoye, Akhalkalaki uezd in 1863; Terpeniye, Kars okrug in 1886; Troitskoye (NR), Saskatchewan in 1899; Uspeniye (NR) in 1908; Ootischenia, British Columbia in 1912.

SHISHIKIN (shishik < shishka or 'cone', 'lump', 'bigshot', 'boss'). Of the household of Grigory Petrovich Kalmykov (b. 1831) of Goreloye village, recorded in the cameral list of Akhalkalaki uezd in 1873. Kalmykov may have been nicknamed shishik because of some swelling or bump on his body (in the literal sense) or because he was a bigwig or hotshot (in the figurative sense).

SHKADRONOV (shkadron or 'squadron'). Of the household of Vasily Efimovich Goncharov (b. 1830) of Goreloye village, recorded in the cameral list of Akhalkalaki uezd in 1863. In the 1850s and 1860s, Goncharov led a squadron (shkadron) of mounted Doukhobor Cossacks who patrolled the village and safeguarded the Doukhobor leaders.

SHTEPSELOV. Of the household of Petr Nikolaevich Kalmykov (b. 1908) of Goreloye village, Akhalkalaki uezd. Kalmykov bore a striking resemblance to Shtepsel'('Plug'), a popular Soviet comedic character, who was diminutive in stature and who was always calm, reasonable and correct in every predicament; for this reason, he was nicknamed after him.

SHULIKOV (shulik or 'kite' (bird), 'chicken'). Used by an unidentified Markin family from Goreloye village, Akhalkalaki uezd in the early 20th century. Derived from the dialect nickname shulik, given to a head of household, presumably because of some resemblance with this bird.

SHURKIN (Shurka $<$ Shura $<$ Aleksandr). Of the household of Aleksandr Fedorovich Khudyakov (b. 1900) of Slavyanka village, recorded in the family list of Elisavetpol uezd in 1935.

SILUANOV (Siluan). Of the descendants of 18th century Doukhobor teacher Siluan Kolesnikov (b. circa 1725) of Kirilovka and Terpeniye villages, recorded in the family list of Melitopol uezd in 1841 and 1843. Transferred to Bogdanovka, Akhalkalaki uezd in 1841; Troitskoye, Akhalkalaki uezd in 1843; Karabulakh, Borchali uezd in 1847; Terpeniye, Kars okrug in 1889; Troitskoye (NR), Lyubomirnoye (NR), Uspeniye (NR), Lyubovnoye (NR), Uspeniye (SAR), Saskatchewan in 1899; Slavyanka (SAR) in 1902 and surrounding district in 1907; Brilliant, British Columbia in 1912; and Thrums in 1918.

SITNIKOV (sitnik or 'sieve-maker'). ${ }^{73}$ Of the household of Anisim Grigor'evich Zbitnev (b. 1821) of Novo-Spasskoye village, recorded in the cameral list of Elisavetpol uezd in 1873. Zbitnev and his sons were craftsmen engaged in sieve-making, weaving sieves from horsehair to be used for sifting flour and grain.

SIVKIN (sivka or 'grey-colored'). ${ }^{74}$ Of the household of Grigory Vasil'evich Agafonov (b. 1878) of Slavyanka village, recorded in the family list of Elisavetpol uezd in 1935. A wealthy flour mill

${ }^{72}$ The gulley known as Sergeeva balka near Slavyanka, Elisavetpol (Azerbaijan) was probably named after this family.

73 Prior to adopting Sitnikov, this family was known by the alternate name Frolov.

${ }^{74}$ The bridge known as Sivkin most in Slavyanka, Elisavetpol (Azerbaijan) was named after 
owner in pre-Revolutionary times, Agafonov often came home covered in flour dust, hence the nickname sivka.

SKIRDKOV (skirdka < skirda or 'oblong, tightly packed pile of hay'). Of the household of Fyodor Fedorovich Goncharov (b. 1855) of Goreloye village, recorded in the family list of Akhalkalaki uezd in 1886. Goncharov or a forebear was nicknamed skirdka, perhaps for his skill in laying skirds of hay or because his straightness of figure and slowness of motion resembled a skird.

SKVORTSOV (skvorets or 'starling'). ${ }^{75}$ Of the household of Fyodor Mikhailovich Goncharov (b. 1922) of Goreloye village, Georgia. When he returned to the village after serving in the Great Patriotic War of 1941-1945, Goncharov wore a Soviet military peaked visor cap wherever he went; he was nicknamed skvorets because of the bird-like appearance this gave him.

SLEPOV (slepoy or 'blind'). Of the household of Nikolai Semenovich Antyufeev (b. 1868) of Crescent Valley, recorded in the census of British Columbia in 1921. A Son of Freedom, Antyufeev was blinded by police teargas during a demonstration in the 1920s. He was thereafter known as slepoy. Officially adopted as 'Slepoff' by some family members in the $1920 \mathrm{~s}$.

SOLDATENKOV (soldatenka < soldatka or 'soldier's wife'). Of the household of Agafiya Ivanovna Strelyaeva (b. 1885), widow of Ivan Ivanovich Strelyaev of Slavyanka village, recorded in the family list of Elisavetpol uezd in 1908. Strelyaeva was nicknamed soldatenka after her husband served and died in the Great Patriotic War of 1914-1918. Her son Fyodor Ivanovich Strelyaev was later killed in the Great Patriotic War of 1941-1945.

SOLDATOV (soldat or 'soldier'). Of the household of Miron Ivanovich Kurbatov (b. 1791) of Spasskoye village, recorded in the cameral list of Akhalkalaki uezd in 1863. As a young man, Kurbatov served as a conscript in the Imperial Russian Army.

STARCHIKOV (starichok or 'elder', 'oldster'). ${ }^{76}$ Of the household of Nikolai Vasil'evich Postnikov (b. 1859) of Terpeniye village, recorded in the family list of Kars okrug in 1899. Having injured his legs while loading wagon freight as a young man, Postnikov hobbled slowly with the aid of a cane like an old man, and was thus nicknamed starichok. Transferred to Petrovka (SAR), Saskatchewan in 1899 and surrounding district in 1918.

STARSHINOV (starshina or 'village foreman'). Of the household of Nikolai Antonovich Trofimenkov (b. 1848) of Spasskoye village, recorded in the family list of Akhalkalaki uezd in 1886. During the 1880 s and 1890 s, Trofimenkov was elected starshina to administer village affairs, finance and justice.

STRELKOV (strelka or 'arrow'). Of the household of Mikhail Mikhailovich Popov (b. 1894) of Rodionovka village, recorded in the family list of Akhalkalaki uezd in 1900. Popov was nicknamed strelka, possibly because of his lean physique, reputation for being straightforward and upstanding, or because of his skills as a hunter and marksman. Transferred to Goreloye village in 1900.

STREL'NIKOV (strel'nik or 'rifleman'). Of the household of Ivan Vasil'evich Ziborov (b. 1893) of Slavyanka village, recorded in the family list of Elisavetpol uezd in 1908. An avid hunter, Ziborov collected and traded animal pelts and hides, hence the nickname strel'nik.

SUKHACHOV (sukhach or 'dry', 'thin' or 'hard'). Of the household of Maksim Dmitrovich Sysoev (b. 1770) of Spasskoye village, recorded in the family list of Melitopol uezd in 1844. Susoev or a forebear was nicknamed sukhach, presumably because he embodied this quality. Transferred to Rodionovka, Akhalkalaki uezd and Slavyanka, Elisavetpol uezd in 1842.

this family.

75 Prior to adopting Skvortsov, this family was known by the alternate name Gryakov.

${ }^{76}$ Prior to adopting Starchikov, this family was known by the alternate name Lavrov. 
SUROPOV. Of the household of Mikhail Pavlovich Makhortov (b. 1818) of Orlovka village, recorded in the family list of Akhalkalaki uezd in 1886. From 1895 to 1898, Makhortov and family were exiled to Gori uezd, where they lived on the estate of Georgian prince Zurabov (Zurabishvili). Unlike other landowners, the prince treated the Doukhobor family with great kindness. For this reason, they came to be known by his Georgian name, pronounced in Russian as Suropov. Transferred to Petrovo (SR), Saskatchewan in 1899; Shoreacres, British Columbia in 1914.

SVETLIKOV. Of the household of Polikarp Svetlov (b. circa 1800) of Spasskoye village, recorded in the family list of Melitopol uezd in 1844. His four sons, orphaned at a young age, were sometimes known by this diminutive form of their surname (from svetlo or 'light'). Transferred to Slavyanka, Elisavetpol uezd in 1844; Rodionovka, Akhalkalaki uezd in 1863; Mikhailovo (NR), Rodionovka and Vossianiye (SR), Saskatchewan in 1899; Uspeniye (NR) in 1908; surrounding districts in 1912-1918. 'Svetlikov' officially adopted by some descendants in the 1870s.

TANYUSHIN (Tanyusha < Tanya < Tat'yana). Of the household of Tat'yana Ryl'kova (b. 1846), widow of Vasily Timofeevich Ryl'kov of Orlovka village, recorded in the cameral list of Akhalkalaki uezd in 1863. Transferred to Petrovo (SR), Saskatchewan in 1899 and surrounding district in 1918; Kern county, California in 1906.

TARANOV (Taran). Also known as TARANKOV (Taranka $<$ Taran). Of the household of Taran Tertichnikov (b. circa 1770) of Goreloye village, recorded in the family list of Melitopol uezd in 1842. Transferred to Goreloye, Akhalkalaki uezd in 1842; Ormasheni, Borchali uezd in 1847; Pokrovka, Kars okrug in 1886; Blagodarnoye (SR), Saskatchewan in 1899 and surrounding district in 1910. 'Taranov' officially adopted by descendants in the 1860 s.

TATOSOV (Tatos). ${ }^{77}$ Of the household of Vasily Alekseevich Makaseev (b. circa 1930) of Goreloye village, Georgia. An Armenian named Tatos lived and worked with Makaseev on the collective farm. For this reason, he received this Armenian men's name (meaning 'fatherly') as a nickname.

TAT'YANIN (Tat'yana). Of the household of Tat'yana Ivanovna Tomilina (b. 1830), widow of Mikhail Yakovlevich Tomilin of Goreloye village, recorded in the family list of Akhalkalaki uezd in 1886 .

TELEGIN (telega or 'wagon'). Of the household of Aleksei Semenovich Novokshonov (b. 1831) of Novo-Spasskoye village, recorded in the cameral list of Elisavetpol uezd in 1860. Novokshonov was nicknamed telega because he and his sons built horse-drawn wagons for use in carting freight. Transferred to Spasovka, Kars okrug in 1880; Blagoveshcheniye (SR), Saskatchewan in 1899; Grand Forks, British Columbia in 1912.

TIKHONOV (Tikhon). Of the household of Tikhon Matveevich Popov (b. 1801) of Slavyanka village, recorded in the cameral list of Elisavetpol uezd in 1853. Transferred to Spasovka, Kars okrug in 1880; Pozirayevka (SAR), Saskatchewan in 1899; and surrounding district in 1910. Officially adopted as 'Tekanoff' by some family members in the 1920 s.

TIKHONOV (tikhonya or 'quiet'). Of the household of Luk'yan Evstevich Tarasov (b. 1858) of Slavyanka village, recorded in the family list of Elisavetpol uezd in 1908. Quiet and reserved by nature, Tarasov was nicknamed tikhonya by fellow villagers.

TIMOFEEV (Timofei). ${ }^{78}$ Of the household of Timofei Mikhailovich Agafonov (b. 1890) of Slavyanka village, recorded in the family list of Elisavetpol uezd in 1908.

${ }_{77}$ A saying arose in the village about this name: Tatos Makaseev, poshyol na posev ("Tatos Makaseev went a-sowing.").

${ }^{78}$ Prior to adopting Timofeev, this family was known by the alternate name Arinin. 
TISHANSKY (of or from Tishanka). ${ }^{79}$ Of the household of Grigory Petrovich Nosov (b. 1869) of Orlovka village, recorded in the family list of Akhalkalaki uezd in 1886. Nosov acquired this name because his family originated from the village of Tishanka in Voronezh guberniya in the 18th century. Transferred to Petrovka, Sal'sk okrug in 1922.

TOLSTUKHIN (tolstukha or 'fat woman'). ${ }^{80}$ Of the household of Anna Chernova (1858), widow of Nikolai Timofeevich Chernov of Slavyanka village, recorded in the family list of Elisavetpol uezd in 1886. A rather stout and rotund woman, Chernova was nicknamed tolstukha by her neighbours. Transferred to Sovetnoye (SR), Saskatchewan in 1899; and Khutor (SR) in 1912.

TROFIMENKOV. Of the household of Vasily Trofimovich Trofimov (b. 1780) of Spasskoye village, recorded in the family list of Melitopol uezd in 1841. Impoverished with a large family to feed, Trofimov was alternately known by the diminutive form of his surname (from Trofim). Transferred to Spasskoye and Tambovka, Akhalkalaki uezd in 1841; Pokrovskoye (NR) and Tambovka (SR), Saskatchewan in 1899 and surrounding districts in 1911; Grand Forks and Brilliant, British Columbia in 1912. Officially adopted by some descendants in the 1870 s.

TRUBETSKOY. ${ }^{81}$ Of the household of Petr Ivanovich Trubitsin (b. 1818) of Novo-Goreloye village, recorded in the cameral list of Elisavetpol uezd in 1853. The family was known by this fanciful name, probably because it sounded similar to their own (trubitsa or 'pipe') and not because of any actual association with the Old Russian principality of Trubetsk (from which the name ostensibly derives). Transferred to Gorelovka, Kars okrug in 1880; Blagoveshcheniye (SR), Saskatchewan in 1899; Brilliant, British Columbia in 1912. Officially adopted by descendants as 'Trubetskoff' in the 1910 s.

TRUBITSIN (trubitsa or 'pipe', 'horn'). Of the household of Ivan Sukrutov (b. 1767) of Spasskoye village, recorded in the family list of Melitopol uezd in 1842. Sukrutov or a forebear were nicknamed trubitsa, presumably because he made or played the horn. Transferred to Novo-Goreloye, Elisavetpol uezd in 1842. Officially adopted in the 1840s.

TRUNOV (Trunya < Trofim) ${ }^{82}$ Of the household of Trofim Nikolaevich Smorodin (b. 1852) of Goreloye village, recorded in the family list of Akhalkalaki uezd in 1886. The name was also applied to Smorodin's grandson-in-law, Kuz'ma Alekseevich Oslopov (b. 1908) when he joined the household.

TRUSHIN (Trusha < Mitrusha < Mitrofan). Of the household of Mitrofan Ryl'kov (b. circa 1780) of Terpeniye village, recorded in the family list of Melitopol uezd in 1843. Transferred to Tambovka, Akhalkalaki uezd in 1844; Tambovka (SR), Saskatchewan in 1899 and surrounding district in 1911; Winlaw, British Columbia in 1911.

TRUSIKOV (trusik < trus' or 'rabbit'). Of the household of Fyodor Ivanovich Tomilin (b. 1925) of Goreloye village, Georgia. Tomilin bred rabbits, and received the dialect nickname trusik for this reason.

TSAR'KOV (tsarek < tsar). Of the descendants of Timofey Sukharev (b. circa 1750) of Terpeniye village, recorded in the family list of Melitopol uezd in 1843. After petitioning the Tsar for protection on behalf of Kharkov Doukhobors in 1792, Sukharev was imprisoned for 17 years in a pillory box, in which he could neither stand upright nor lie down; when finally released, he defiantly exclaimed, 'now I am Tsar and God!' He was thus nicknamed tsarek. Transferred to Bogdanovka, Akhalkalaki uezd in 1843; Uspeniye, Sal'sk okrug in 1922.

79 Prior to adopting Tishansky, this family was known by the alternate name Lipatov.

${ }_{80}$ Prior to adopting Tolstukhin, this family was known by the alternate name Mikheev.

${ }^{81}$ Prior to adopting Trubetskoy, this family was known by the alternate name Trubitsin.

${ }^{82}$ Prior to adopting Trunov, this Oslopov family was known by the alternate name Kukanov. 
TSUVAKOV (tsuvaki < chuvaki or 'heelless leather shoes' in Turkic, Georgian and Armenian). Used by an unidentified Markin family from Goreloye village, Georgia. A head of household may have been nicknamed tsuvaki because he made or wore this popular Caucasian footwear.

UL'YASHIN (Ul'yasha < Ul'yana). Of the household of Ul'yana Chernenkova (b. 1807), widow of Rodion Vasil'evich Chernenkov of Bogdanovka village, recorded in the cameral list of Akhalkalaki uezd in 1863. Transferred to Bogdanovka and Tikhomirnoye (NR), Saskatchewan in 1899 and surrounding districts in 1910; Bogomdannoye (NR) in 1905; Glade, Brilliant and Shoreacres, British Columbia in 1912.

UL'YASHIN (Ul'yasha < Ul'yana). Of the household of Ul'yana Rybalkina (b. 1874), wife of Vasily Ivanovich Rybalkin of Novo-Goreloye village, Elisavetpol uezd.

UTKIN ( utka or 'duck'). Of the household of Mikhail Manuilovich Fofanov (b. 1826) of Efremovka village, recorded in the cameral list of Akhalkalaki uezd in 1873. Fofanov or a forebear may have received the nickname $u t k a$ because he kept ducks, or possessed some quality characteristic of a duck.

UVERENNIYE ('assured of' or 'convinced'). Of the household of Mikhail Vasil'evich Medvedev (b. 1888) of Tambovka village (SR), recorded in the census of Saskatchewan in 1911. This name was bestowed upon Medvedev by Doukhobor leader Petr Vasil'evich Verigin because of his stalwart faith and belief. Transferred to Ootischenia, British Columbia in 1912. Officially adopted as 'Overennay' by family members in the 1920 s.

VAKULIKH (Vakul). Of the household of Vakul Vakulovich Strelyaev (b. 1829) of Novo-Spasskoye village, recorded in the cameral list of Elisavetpol uezd in 1873. Transferred to Spasovka, Kars okrug in 1880; Moiseyevo (GSA) in 1899; surrounding district in 1912; and Pass Creek, British Columbia in 1912.

VANIN (Vanya < Ivan). Of the household of Ivan Alekseevich Kalmykov (b. 1806) of Novo-Goreloye village, recorded in the cameral list of Elisavetpol uezd in 1860. Transferred to Staro-Goreloye and Novo-Goreloye (GSA), Saskatchewan in 1899; and surrounding district in 1907.

VASILYUSHKIN (Vasilyushka < Vasily). Also known as VASIL'CHIKOV (Vasil'chik < Vasily). Of the household of Vasily Petrovich Trofimenkov (b. 1860) of Spasskoye village, recorded in the family list of Akhalkalaki uezd in 1886. Transferred to Khlebodarnoye, Sal'sk okrug in 1922.

VASIN (Vasya < Vasily). Used by an unidentified family from Akhalkalaki uezd in the late 19th century. Derived from the diminutive name of the head of household.

VASYUNIN (Vasyunya < Vasilisa) ${ }^{83}$ Of the household of Vasilisa Vasil'evna Agafonova (b. 1936), wife of Mikhail Andreevich Agafonov of Slavyanka village, Azerbaijan. In 1951 and 1963, Agafonova was awarded the title 'Hero of the Soviet Union' for outstanding achievements in the development of agricultural production as foreman of the collective farm 'Put' Il'icha'.

VIKHTARYONKOV (Vikhtaryonka $<$ Vikhtar $<$ Viktor). Of the household of Viktor Gololobov (b. circa 1785) of Goreloye village, recorded in the family list of Melitopol uezd in 1845. Transferred to Goreloye, Akhalkalaki uezd in 1845.

YANIN (Yan < Averyan, Gordian, Sever'yan, Arian, Ioann). Used by an unidentified family from Elisavetpol uezd and transferred to Terpeniye, Kars okrug in 1880. Derived from the diminutive name of the head of household.

YAREV (yar or 'ravine'; yara or 'spring'; yara or 'wound' in Turkic). Used by an unidentified Krasnikov family from Goreloye village, Akhalkalaki uezd in the early 20th century. Derived from

\footnotetext{
${ }^{83}$ Prior to adopting Vasyunin, this family was known by the alternate name Karabekov.
} 
the nickname yar, given to a head of household because of some association with a ravine or steep bank; the dialect term yara because of an association with the spring season; or the Turkic term yara because of a wound or injury.

YASHIN (Yasha < Yakov). Of the household of Yakov Vasil'evich Kalmykov (b. 1817) of Novo-Goreloye village, recorded in the cameral list of Elisavetpol uezd in 1860. Transferred to Novo-Goreloye (GSA), Saskatchewan in 1899; Moiseyevo (GSA) in 1908; surrounding district in 1912; and Shoreacres, British Columbia in 1912.

YASTREBOV (yastreb or 'hawk'). This name is a misinterpretation of 'Istrebov' (through folk etymology) by some Doukhobors who misapplied it to Petr Petrovich Verigin (b. 1904), proclaimed leader in absentia of Community Doukhobors in Canada in 1939. It was later appropriated by Stefan Sevastyanovich Sorokin (b. 1902), controversial Sons of Freedom leader from 1950 to 1984.

ZAICHIKOV (zaichik< zayats or 'hare'). Of the household of Nikolai Nikolayevich Tolmachev (b. 1923) of Goreloye village, Georgia. Tolmachev was nicknamed zaichik because of his hare-like speed and reflexes.

ZAMYATKIN (zamyatka or 'excitement', 'distemper' or 'anxiety'). Of the household of Fyodor Ivanovich Petrov (b. 1846) of Spasskoye village, recorded in the family list of Akhalkalaki uezd in 1886. Most likely, Petrov was nicknamed zamyatka as a young child because he was a noisy and restless. Transferred to Khlebodarnoye, Sal'sk okrug in 1922.

ZAKHARUSHKIN (Zakharushka < Zakhar). Of the household of Zakhar Filippovich Postnikov (b. 1805) of Slavyanka village, recorded in the cameral list of Elisavetpol uezd in 1853. Transferred to Terpeniye, Kars okrug in 1880; Uspeniye (SAR), Saskatchewan in 1899 and surrounding district in 1902; Slavyanka (SAR) in 1902; Brilliant and Champion Creek, British Columbia in 1912.

ZAKHARUSHKIN (Zakharushka $<$ Zakhar) ${ }^{84}$ Of the household of Zakhar Mikhailovich Sukhorukov (b. 1821) of Goreloye village, recorded in the cameral list of Akhalkalaki uezd in 1863. Transferred to Spasskoye village in the 1900s.

ZHIKHAREV. ${ }^{85}$ Of the household of Vasily Semenovich Semenov (b. 1813) of Slavyanka village, recorded in the cameral list of Elisavetpol uezd in 1853. Zhikharev (zhikhar or 'daring') is believed to be the maiden name of his wife Anastas'ya (b. 1813) which became extinct in the male line of her family. ${ }^{86}$ Transferred to Gorelovka and Spasovka, Kars okrug in 1880; Otradnoye (SR), Spasovka (SR), Malo-Gorelovka (SAR), Saskatchewan in 1899 and surrounding districts in 1911-1918; Novoye (SR) in 1905; Grand Forks and Brilliant, British Columbia in 1912.

ZHIRKHOV (zhirukha or 'wretch', 'knave', 'rogue' or 'glutton'). Used by an unidentified Goncharov family from Bashkichet village, Borchali uezd in the late 19th century. Derived from the nickname zhirukha, given to a head of household who matched this description in some way.

ZONTIKOV (zontik or 'umbrella', 'parasol'). Used by an unidentified Krasnikov family from Goreloye village, Akhalkalaki uezd in the early 20th century. Derived from the nickname zontik, given to a head of household, presumably because he often carried an umbrella.

${ }^{84}$ Prior to adopting Zakharushkin, this family was known by the alternate name Mikhailin.

${ }^{85}$ The Doukhobor settlement Zhikharevo or "Zhikhareff village" in the Grand Forks district of British Columbia (1908-1938) received its name from this family.

${ }^{86}$ The last male member of the original Doukhobor family, Fotei Ivanovich Zhikharev (b. 1771), died in Terpeniye village, Akhalkalaki uezd in the 1840s. 


\title{
SUMMARY
}

\section{ULICHNYE FAMILII AMONG DOUKHOBORS OF THE CAUCASUS AND CANADA}

\begin{abstract}
A longstanding folk tradition among rural Russian peasants, ulichnye familii ('street surnames') were used by Doukhobors colloquially 'on the street' of a village to distinguish among families sharing the same official surname. Similar to Quebecois dit names and Scottish sept names, ulichnye familii arose because of the low surname stock within Doukhobor society. Passed down to succeeding generations and transferred between settlements, these names became a recognized form of address among Doukhobors, helping structure kinship networks and organize social interactions among villagers. When a large contingent of Doukhobors emigrated from the Caucasus to the Canadian prairies in 1899 , they continued this naming practice in their settlements well into the early 20th century. A ubiquitous part of their culture for generations, today ulichnye familii have all but disappeared among Doukhobors, as a result of their assimilation, dispersal and modernization. This article offers an analysis of the Doukhobor anthroponymic custom of ulichnye familii: the social factors leading to their adoption; the etymological processes through which these names were formed; the manner in which they were used and transmitted; and the elements contributing to their eventual decline and disuse. It also includes an inventory of extant ulichnye familii among the Doukhobors of the Caucasus and Canada, obtained through extensive field interviews and archival research.
\end{abstract}

\section{STRESZCZENIE}

\section{ULICHNYE FAMILII U DUCHOBORCÓW Z KAUKAZU I KANADY}

Wśród wiejskiej ludności rosyjskiej, zgodnie z ludową tradycją, używane były specyficzne nazwiska nieoficjalne, tzw. ulichnye familii (przydomki). Zwyczaj ten był znany również wśród duchoborców (wspólnoty religijnej wywodzącej się z prawosławia) w Rosji i na Zakaukaziu. Rodziny o tym samym nazwisku używały dodatkowych określeń, które powstawały na skutek niewielkiego zasobu nazwisk w tej społeczności i problemów identyfikacyjnych. Przydomki te, przekazywane następnym pokoleniom, przenoszone między osadami, stały się uznaną formacją antroponimiczną, pomagającą w budowaniu sieci pokrewieństwa i organizowaniu życia społecznego mieszkańców wsi. Kiedy duchoborcy wyemigrowali do Kanady w 1899 roku, kontynuowali tę praktykę nazewniczą aż do początku XX wieku. Współcześnie ulichnye familii zniknęły niemal wśród tej wspólnoty w wyniku tendencji asymilacyjnych, rozproszenia tej zwartej kiedyś grupy i modernizacji społeczeństwa.

Artykuł przedstawia analizę onomastyczną tego typu nazw zwyczajowych: czynniki społeczne sprzyjające ich powstaniu, procesy nazwotwórcze, sposób, w jaki były używane i przekazywane, oraz przyczyny ich zaniku. Do artykułu dołączono spis nieoficjalnych nazwisk duchoborców zebranych podczas wywiadów terenowych i badań dokumentów archiwalnych.

Słowa tematyczne: duchoborcy, Rosja, Kaukaz, Kanada, przydomek, nazwisko, zwyczaj ludowy 